\title{
SPATIAL VARIABILITY OF SOIL CO2 EMISSION IN SOYBEAN AND SUGARCANE AREAS IN MATO GROSSO DO SUL CERRADO, BRAZIL
}

\author{
Maira Caroline Terçariol ${ }^{1}$; Vivian Aparecida Brancaglioni ${ }^{1}$; José Paulo Artêncio Júnior ${ }^{1}$; Rafael \\ Montanari3 ; Marcelo Carvalho Minhoto Teixeira Filho ${ }^{3}$; Antonio César Bolonhezi³ ${ }^{3}$ Newton La Scala \\ Júnior ${ }^{2}$; Fabio Roberto Chavarette ${ }^{3}$ and Alan Rodrigo Panosso ${ }^{3, *}$ \\ ${ }^{1}$ Graduate student, UNESP - FEIS, Avenida Brasil 56, 15385-000, Ilha Solteira, SP, Brazil. ${ }^{2}$ UNESP - FCAV Professor, Via \\ de Acesso Prof. Paulo Donato Castellane s/n, 14884-900 - Jaboticabal, SP, Brazil. ${ }^{3}$ UNESP - FEIS Professor, Avenida Brasil \\ 56, 15385-000, Ilha Solteira, SP, Brazil. \\ *Corresponding author: alanrp@mat.feis.unesp.br
}

\begin{abstract}
In last years, the damage caused to the environment due to anthropic activities have become a worldwide concern. The carbon dioxide $\left(\mathrm{CO}_{2}\right)$ is one of the main greenhouse gases because the increase of its concentration in the atmosphere has intensified to global warming. Therefore, to study the $\mathrm{CO}_{2}$ amounts emitted to the atmosphere has been even more important, especially in agricultural areas in Brazil. This study aimed to determine the spatial variability of soil $\mathrm{CO}_{2}$ emissions $\left(\mathrm{FCO}_{2}\right)$, soil temperature (Ts) and soil moisture (Ms) in soybean and sugarcane cultivation areas in the Cerrado region in Mato Grosso do Sul. The $\mathrm{FCO}_{2}$ and Ts registration were done using a portable flow chamber and temperature sensor of the LI-8100 system. The Ms was evaluated using TDR portable system. The studies were conducted in the years of 2013, in soybean cultivation, and in 2014, in the sugarcane cultivation, during the crop growth early stages, using grids which contain 89 and 102 sampling points, respectively, spanning 1 ha area in both experiments. The spatial variability variables were characterised by geostatistics: mathematical models adjustments to the experimental variograms and spatial pattern maps construction through ordinary kriging technique. The $\mathrm{sTe} s \mathrm{H}$ variables did not show significant correlations with $\mathrm{FCO}_{2}$. Despite the years of conducting the experiments, the soybean cultivation presented the higher average values of soil $\mathrm{CO}_{2}$ emission equal $2.11 \mu \mathrm{mol} \mathrm{m}^{-2} \mathrm{~s}^{-1}$ and higher variation in range of the spatial dependency between 8.41 and $27 \mathrm{~m}$ when compared to sugarcane culture, with a $\mathrm{FCO}_{2}$ average of $1.71 \mu \mathrm{mol} \mathrm{m} \mathrm{m}^{-2} \mathrm{~s}^{-1}$ and variation in the ranges of spatial dependency between 15.3 and $27.3 \mathrm{~m}$.
\end{abstract}

Key words: geostatistics, soil respiration, soil attributes, agricultural management.

\section{VARIABILIDADE ESPACIAL DA EMISSÃO DE CO2 DO SOLO EM ÁREAS DE SOJA E CANA- DE-AÇÚRCAR NO CERRADO MATO GROSSO DO SUL, BRASIL}

RESUMO: Nos últimos anos, os danos gerados ao meio-ambiente devido às ações antrópicas se tornaram uma preocupação mundial. O dióxido de carbono $\left(\mathrm{CO}_{2}\right)$ é um dos principais gases estufas, pois o aumento de sua concentração na atmosfera terrestre tem intensificado o aquecimento global. Portanto, estudar as quantidades de $\mathrm{CO}_{2}$ emitido para a atmosfera tem sido cada vez mais importante, principalmente em áreas agrícolas no Brasil. O objetivo do trabalho foi determinar a variabilidade espacial da emissão de $\mathrm{CO}_{2}$ (FCO2), temperatura (Ts) e umidade (Us) do solo em áreas de cultivo de soja e cana-de-açúcar na região do Cerrado no Mato Grosso do Sul. FCO2 e Ts foram registradas utilizando-se de câmara de fluxo portátil e sensor de temperatura do sistema LI-8100. A umidade foi avaliada utilizando sistema portátil TDR. Os estudos foram conduzidos nos anos de 2013, na cultura da soja, e no ano de 2014, na cultura da cana-de-açúcar, durante os estágios inicias do crescimento das culturas, utilizando-se gradeados de contendo 89 e 102 pontos amostrais, respectivamente, abrangendo área de 1 ha nos dois experimentos. A variabilidade espacial das variáveis foi caracteriza pela geoestatística, ajustes de modelos matemáticos aos variogramas experimentais e construção dos mapas de padrão espacial por meio da técnica de krigagem ordinária. A variáveis Ts e Us não apresentaram correlações significativas com FCO2.A despeito dos anos de condução dos experimentos, a cultura da soja os maiores valores de média de emissão de $\mathrm{CO}_{2}$ do solo igual $2,11 \mu \mathrm{mol} \mathrm{m} \mathrm{m}^{-2} \mathrm{~s}^{-1}$ e maior variação nos alcances de dependência entre 8,41 e $27 \mathrm{~m}$ quando comparados a cultura de cana-de-açúcar com média de $1,71 \mu \mathrm{mol} \mathrm{m} \mathrm{m}^{-2} \mathrm{~s}^{-1} \mathrm{e}$ variação nos valores de alcance entre 15,3 e 27,3 m.

Palavras-chave: geoestatística, respiração do solo, atributos do solo, manejo agrícola.

Received: Sep. 07, 2016 - Accepted: Dec. 22, 2016 


\section{INTRODUCTION}

The greenhouse effect is a natural phenomenon responsible for maintaining the planet's temperature at levels, which provide the life on Earth, as we know it. After the industrial revolution, large amounts of the called greenhouse gases (GEE - $\mathrm{CO}_{2}, \mathrm{CH}_{4}$ e $\mathrm{N}_{2} \mathrm{O}$ ) are being launched to the atmosphere intensifying this phenomenon. The additional greenhouse effect has altered in a worrying way, the planet climatic conditions, generating environment, agricultural and livestock activities and to human health damage. In this context, according to IPCC (Intergovernmental Panel on Climate Change IPCC, 2014), world agriculture is responsible for significant amounts of anthropogenic emissions of these gases to the atmosphere, contributing with 11.78 to $58 \%$ of the emission. In Brazilian agriculture $\mathrm{CO}_{2}$ emissions, corresponds to $75 \%$ of total GEE anthropogenic emissions (CERRI et al., 2007). The soils present an important role in these emissions because, it can be understood that agricultural soils are the carbon sources or drains to the atmosphere, depending on its management, which affects the soil physical, chemical, and biological attributes, which act directly on the carbon loss process by the soil.

According to Rayment \& Jarvis (2000), the carbon balance in an ecosystem is represented by the amounts of absorbed carbon by the photosynthesis and the amount of lost carbon during soil respiration process. Small increments in respiration rates may be enough to change an ecosystem of carbon sink source to the atmosphere (Buczko et al., 2015). However, emissions from the soil, often are not considered in the calculation, due to its great spatial-temporal variation and by being a resulting phenomenon from a complex interaction of physical, chemical and biological soil attributes and climatic factors (Schwendenmann et al., 2003; Epron et al., 2006; Lal, 2009; Teixeira et al., 2012; SilvaOlaya et al., 2013; Buczo et al., 2015; lamaguti et al., 2015; Moitinho et al., 2015). Therefore, studies that seek to characterise the spatialtemporal variability patterns of $\mathrm{CO}_{2}$ emission and its relation with soil attributes are important in determining the carbon balance, especially, in agricultural ecosystems.

According to the Agriculture, Livestock and Supply Ministry (ALSM, 2016), the soybean is a featured culture in the country corresponding to $49 \%$ of the grain planted area, being the Midwest the main producer of this oleaginous plant. According to the National Supply Company (CONAB, 2015a) Brazilian grain harvest 2015/16 will be of 101.2 million of grain. Another great relevance culture in the country is the sugarcane, with the great feature of production in the country southeast, being São Paulo state, the higher national producer. The 2015/16 harvest should produce 655.16 million tonnes in about 8.95 million hectares (CONAB, 2015b).

The geostatistics is the tool that studies the autocorrelation of the soil attributes, in other words, the spatial dependence, and provides great techniques variety to incorporate the spatial coordinates of the observations in the analysis. The soil carbon loss by the $\mathrm{CO}_{2}$ emission varies in space, depending on environmental conditions, soil characteristics and adopted agricultural management. This information can be used for defining the adequate agricultural 
practices of soil management, besides to evaluate agriculture effects on environmental quality, from the point of view of the soil organic matter maintenance and by reducing the $\mathrm{CO}_{2}$ atmospheric emissions. Thus, study and characterize aspects connected to the spatial variability of soil $\mathrm{CO}_{2}$ emission in agricultural areas is of fundamental importance for a better understanding of this phenomenon and from its controlling factors (Isaaks \& Srivastava, 1989; Webster \& Oliver, 2009). This way, in view of the presented, the aim of this work was to determine the spatial variability structure of $\mathrm{CO}_{2}$ emissions and possible relations with the soil moisture and soil temperature in soybean and sugarcane cultivation areas in Cerrado region from Mato Grosso do Sul, Brazil.

\section{MATERIAL AND METHODS}

The soybean cultivation study (Cultivate Valiosa RR- Glycine max - L. Merril), was conducted in the year of 2013 in the experimental area of the Educational Farm, Research, and Extension - Sector of Vegetal Production of Ilha Solteira Engineering Faculty (FEIS/UNESP) located in Selvíria city (MS). The geographical area coordinates are $20^{\circ} 18^{\prime} 05^{\prime \prime}$ of south latitude and $52^{\circ} 40^{\prime} 28^{\prime \prime}$ of West longitude, with an elevation of $360 \mathrm{~m}$ above sea level. The annual average of rainfall was $1595 \mathrm{~mm}$, with a temperature average of 23.7 ${ }^{\circ} \mathrm{C}$. The experimental area soil was classified as distroferric Red Latosol clayey typical, with homogeneous slope $0,025 \mathrm{~m} \mathrm{~m}^{-1}$ (EMBRAPA, 2013). Due to the possible non-uniformity of the spacing between the culture planting lines, the sampling mesh was $50 \times 50 \mathrm{~m}$ containing 133 sampling points, symmetric and with minimum separation distances between points of $0.5 \mathrm{~m}$.

The sugarcane culture study (Cultivate CTC 1- Saccharum spp.) was conducted in the year of 2014, being the green management sugarcane production system (mechanical harvesting without the previous burning of sugarcane fields), in commercial planting area in Aparecida do Taboado city in Mato Grosso do Sul State, Brazil. The geographical area coordinates are $20^{\circ} 16^{\prime} 03^{\prime \prime}$ of south latitude and $51^{\circ} 16^{\prime} 04^{\prime \prime}$ of West longitude, with an elevation of $370 \mathrm{~m}$ above sea level and the annual average of rainfall was $1595 \mathrm{~mm}$. The experimental area soil was classified as distroferric Red Latosol clayey typical (Oxisol), with homogeneous slope 0,025 $\mathrm{m} \mathrm{m}^{-1}$ (EMBRAPA, 2013). A regular railing of $100 \times$ $100 \mathrm{~m}$ was installed containing 102 sampling points with minimum separation distances between $5 \mathrm{~m}$ points in the densification regions.

The soil $\mathrm{CO}_{2}$ emission $\left(\mathrm{FCO}_{2}\right)$ was registered through two LI-COR systems (LI8100). In its measurement mode, the system monitors the changes in the $\mathrm{CO}_{2}$ concentration inside the chamber, through the spectroscopy in the infrared region. The soil chamber has an internal volume of 854.2 $\mathrm{cm}^{3}$ with a circular contact area of $83.7 \mathrm{~cm} 2$. This chamber was placed on PVC collars previously inserted into the soil at each mesh point in the depth of $3 \mathrm{~cm}$. The $\mathrm{CO}_{2}$ flow was computed in each point by adjustment of the $\mathrm{CO}_{2}$ concentration of the air inside the chamber according to a parabolic regression in time after closing the same. The soil temperature (Ts) was monitored concomitantly to the soil respiration evaluations using a temperature sensor that is 
part of the LI-8100 system. Such sensor consists of a $20 \mathrm{~cm}$ rod that was inserted into the soil in a region close to the PVC collars. The soil moisture (Ms) was determined through of a TDR (Time Domain Reflectometry - Hydrosense TM, Campbell Scientific, Australia) device. The TDR device is constituted by a probe, presenting two $12 \mathrm{~cm}$ rods, inserted into the soil in a region near to the PVC collars.

In the soybean experiment, the $\mathrm{FCO}_{2}$, Ts, and Ms assessments were performed in the Julian days 323, 327, 330, 332, 337, 339 and 344 , such days comprises the period from November 19 to December 10, 2013. For the sugarcane experiment, the assessments were performed in the Julian days 184, 186, 188, 190, 191 and 193, which comprise the experimental period of July 3 to 14, 2014. For the day's' count, was assigned the 1st day to January 1 st of each respective year. All the evaluations were performed in the period of the morning from 8 to 11 hours.

The results were presented in terms of descriptive statistics (average, variance, standard deviation, standard error of the average, minimum, maximum and variation coefficient, asymmetry and kurtosis). The relation between $\mathrm{FCO}_{2}$ in the study days and the soil attributes were determined by calculating Pearson linear correlation coefficient at $5 \%$ probability level. The spatial dependence of each variable was determined by the experimental variogram analysis (Webster \& Oliver, 1990). The semi-variance estimate, in a given separation distance $h$, was determined by the formula:

$$
\hat{\gamma}(h)=\frac{1}{2 N(h)} \sum_{i=1}^{N(h)}\left[Z\left(x_{i}\right)-Z\left(x_{i}+h\right)\right]^{2}
$$

wherein $N(h)$ is the pairs of point number separated by the distance $h, Z\left(x_{i}\right)$ is the $Z$ variable value at the point $x_{i}$ and $Z\left(x_{i}+h\right)$ is the variable value $Z$ at the point $x_{i}+h$.

The experimental variograms were fitted by theoretical models following:

a) exponential model:

$$
\hat{\gamma}(h)=C_{0}+C_{1}\{1-\exp [-3(h / a)]\}, \mathrm{h}>0 \text {; }
$$

b) spherical model:

$$
\begin{aligned}
& \hat{\gamma}(h)=C_{0}+C_{1}\left[3 / 2(h / a)-1 / 2(h / a)^{3}\right\rfloor, 0 \leq h \leq a \\
& \text { and } \hat{\gamma}(h)=C_{0}+C_{1}, \mathrm{~h}>\mathrm{a} \text {. and }
\end{aligned}
$$

c) Gaussian model:

$$
\hat{\gamma}(h)=C_{0}+C_{1}\left\{1-\exp \left[-3(h / a)^{2}\right]\right\}, 0<\mathrm{h}<\mathrm{d}
$$

being $d$ the maximum distance at which the variogram is defined. The choice of the bestadjusted model to the experimental variogram was carried out by crossed validation technique, which consists of the removal of each observation belonging to the data set with a subsequent estimate of its value, by the interpolation method (ordinary kriging). The chosen model was those that best estimated the observed values, in other words, that which produced a linear regression equation between the observed values according to the estimated values the closest to the bisecting - intercept equal to zero and angular coefficient equal to unity (Isaaks \& Srivastava, 1989).

The parameters of the adjusted models to the experimental variograms were used in the estimation of the studied attributes in unsampled locations, for the spatial patterns 
maps construction, by the ordinary kriging technique:

$$
Z *\left(x_{0}\right)=\sum_{i=1}^{N} \lambda_{i} Z\left(x_{i}\right)
$$

\section{RESULTS AND DISCUSSION}

Table 1 presents the soil chemicals attributes average values in the two study areas. By analyzing the average values was noted that, for the soybean area: $\mathrm{P}$ level was $18.82 \mathrm{mg} \mathrm{dm}^{-3}$; $\mathrm{pH}$ equal to 4.69; $\mathrm{H}+\mathrm{Al}$ of $34.65 \mathrm{mmolc} \mathrm{dm}^{-3}$; for Bases is $23.75 \mathrm{mmolc}$ $\mathrm{dm}^{-3}$; CEC equal to $58.47 \mathrm{mmolc} \mathrm{dm}^{-3}$ and finally to $V$ is $40.60 \%$. For the cane area: $P$ was $9.05 \mathrm{mg} \mathrm{dm}^{-3}$; $\mathrm{pH}$ equal to $5.32 ; \mathrm{H}+\mathrm{Al}$ of 24.64 mmolc dm-3; for Bases is 34.07 mmolc $\mathrm{dm}^{-3}$; CEC equal to $58.73 \mathrm{mmolc} \mathrm{dm}^{-3}$ and finally to $V$ is $56.95 \%$. For the sugarcane area, was noted a high Value of organic matter $19.60 \mathrm{~g} \mathrm{dm}^{-3}$ when compared with the value of $17.59 \mathrm{~g} \mathrm{dm}^{-3}$ of soybean area, being the organic matter (OM) one of the main sources of $\mathrm{CO}_{2}$ production in the soil, promoted by microbiological activity (Ball et al., 1999; Dominy \& van Antwerpen, 2002; Kemmitt et al., 2008).

Table 1. Initial analysis of some chemical attributes for soil fertility purposes studied in the layer of 0-0.1 m depth.

\begin{tabular}{|c|c|c|c|c|c|c|c|c|c|c|}
\hline Cultures & SOM & $\begin{array}{c}\mathrm{pH} \\
\mathrm{CaCl}_{2}\end{array}$ & $P$ & $\mathrm{~K}^{+}$ & $\mathrm{Ca}^{2+}$ & $\mathrm{Mg}^{2+}$ & $\mathrm{H}^{+}+\mathrm{Al}^{3+}$ & Bases & CEC & V \\
\hline & $\mathrm{g} \mathrm{dm}^{-3}$ & & $\mathrm{mg} \mathrm{dm} \mathrm{m}^{-3}$ & - - & ------ & - & -- $\mathrm{mmol}_{\mathrm{c}} \mathrm{dm}$ & 3 ------- & --------- & $\%$ \\
\hline Soybean & 17.59 & 4.69 & 18.82 & 2.22 & 11.29 & 10.28 & 34.65 & 23.75 & 58.47 & 40.60 \\
\hline Sugarcane & 19.60 & 5.32 & 9.05 & 1.42 & 12.43 & 10.27 & 24.64 & 34.07 & 58.73 & 56.95 \\
\hline
\end{tabular}

Despite the experiments conducting occur in different years, for the soybean experiment, the $\mathrm{FCO}_{2}$ average ranged from $1.34 \mu \mathrm{mol} \mathrm{m} \mathrm{m}^{-2} \mathrm{~s}^{-1}$ (day 332) to $4.07 \mu \mathrm{mol} \mathrm{m} \mathrm{m}^{-2} \mathrm{~s}^{-}$ ${ }^{1}$ (day 323 ) during the 21 days of study, on the other hand, for the sugarcane area experiment, the $\mathrm{FCO}_{2}$ average ranged from $1.15 \mu \mathrm{mol} \mathrm{m}{ }^{-2} \mathrm{~s}^{-1}$ (day 186) to $3.37 \mu \mathrm{mol} \mathrm{m} \mathrm{m}^{-2} \mathrm{~s}^{-}$ 1 (day 191) during the period of 9 days of study (Table 2). Such averages were similar to those observed in other studies conducted in areas of soybean/maize fallow period, and sugarcane areas carried out in Red Latosol in Jaboticabal region, SP (La Sacala et al., 2000a; La Sacala et al., 2003; Panosso et al., 2012; Bicalho et al., 2014). In addition, these values can be compared to those observed in recent studies where the spatial variability of $\mathrm{FCO}_{2}$ 
was evaluated in the sugarcane culture in Red Latosol areas nearby Pradópolis city, SP, Brazil
(Panosso et al., 2008; Brito et al., 2010; Panosso et al., 2012; Bicalho et al., 2014).

Table 2. Descriptive statistics of soil $\mathrm{CO}_{2}$ emission, soil temperature and soil moisture for studied days of the year 2013 in soybean and for the year 2014 in sugarcane.

\begin{tabular}{|c|c|c|c|c|c|c|c|c|c|c|}
\hline \multirow{2}{*}{ Julian day } & Average & Med & $\mathrm{SE}$ & Min & Max & VC & Q1 & Q3 & Skewn & Kurt \\
\hline & \multicolumn{10}{|c|}{ Soybean (2013) } \\
\hline \multicolumn{11}{|c|}{ Soil $\mathrm{CO}_{2}$ emission $\left(\mu \mathrm{mol} \mathrm{m} \mathrm{m}^{-2} \mathrm{~s}^{-1}\right)$} \\
\hline 323 & 4.07 & 3.79 & 0.19 & -0.11 & 14.03 & 52.85 & 2.70 & 4.87 & 1.55 & 0.03 \\
\hline 327 & 2.27 & 1.98 & 0.13 & 0.12 & 9.38 & 64.05 & 1.40 & 2.61 & 2.19 & 0.05 \\
\hline 330 & 1.97 & 1.75 & 0.09 & -0.01 & 5.25 & 53.73 & 1.27 & 2.44 & 1.04 & 0.01 \\
\hline 332 & 1.34 & 1.23 & 0.05 & -0.01 & 3.11 & 43.33 & 0.97 & 1.67 & 0.75 & 0.00 \\
\hline 337 & 1.88 & 1.68 & 0.08 & 0.03 & 7.00 & 48.97 & 1.31 & 2.19 & 1.98 & 0.05 \\
\hline 339 & 1.35 & 1.24 & 0.05 & -0.10 & 3.73 & 44.15 & 0.96 & 1.66 & 0.88 & 0.02 \\
\hline 344 & 1.94 & 2.12 & 0.08 & -1.25 & 5.06 & 42.68 & 1.51 & 2.64 & 0.43 & 0.01 \\
\hline \multicolumn{11}{|c|}{ Soil Temperature(Co) } \\
\hline 323 & 27.66 & 27.63 & 0.06 & 24.23 & 29.21 & 2.62 & 27.14 & 28.20 & -0.61 & 0.02 \\
\hline 327 & 25.68 & 25.68 & 0.03 & 24.82 & 26.54 & 1.45 & 25.39 & 25.97 & 0.04 & 0.00 \\
\hline 330 & 26.39 & 26.38 & 0.05 & 24.91 & 27.71 & 2.18 & 25.99 & 26.79 & -0.13 & 0.00 \\
\hline 332 & 28.62 & 28.63 & 0.06 & 27.10 & 30.00 & 2.55 & 28.00 & 29.20 & 0.07 & -0.01 \\
\hline 337 & 27.28 & 27.15 & 0.09 & 25.49 & 29.70 & 3.79 & 26.46 & 27.85 & 0.49 & -0.01 \\
\hline 339 & 29.08 & 29.14 & 0.05 & 28.02 & 30.00 & 1.82 & 28.59 & 29.50 & -0.03 & -0.02 \\
\hline 344 & 28.07 & 28.11 & 0.03 & 27.20 & 28.99 & 1.39 & 27.80 & 28.35 & -0.14 & -0.01 \\
\hline \multicolumn{11}{|c|}{ Soil Moisture (\% volume) } \\
\hline 323 & 23.00 & 24.00 & 0.13 & 18.50 & 24.00 & 6.43 & 23.00 & 24.00 & -1.73 & 0.02 \\
\hline 327 & 20.69 & 20.71 & 0.14 & 16.88 & 26.29 & 7.96 & 19.76 & 21.52 & 0.16 & 0.00 \\
\hline 330 & 18.95 & 19.00 & 0.23 & 13.67 & 28.00 & 14.00 & 17.00 & 20.33 & 0.38 & 0.00 \\
\hline 332 & 15.05 & 15.00 & 0.15 & 11.00 & 24.50 & 11.71 & 13.80 & 15.88 & 1.35 & 0.04 \\
\hline 337 & 12.74 & 12.67 & 0.13 & 8.67 & 17.00 & 12.16 & 11.67 & 13.67 & 0.48 & 0.00 \\
\hline 339 & 11.53 & 11.50 & 0.11 & 8.00 & 15.00 & 11.46 & 10.54 & 12.25 & 0.14 & 0.00 \\
\hline 344 & 18.25 & 18.67 & 0.25 & 12.33 & 25.33 & 15.72 & 16.00 & 20.00 & 0.17 & 0.00 \\
\hline \multicolumn{11}{|c|}{ Sugarcane (2014) } \\
\hline \multicolumn{11}{|c|}{ Soil $\mathrm{CO}_{2}$ emission $\left(\mu \mathrm{mol} \mathrm{m} \mathrm{m}^{-2} \mathrm{~s}^{-1}\right)$} \\
\hline 184 & 1.47 & 1.48 & 0.06 & 0.15 & 3.2 & 39.63 & 1.10 & 1.72 & 0.6 & 0.01 \\
\hline 186 & 1.15 & 1.1 & 0.06 & 0.1 & 3.81 & 52.28 & 0.85 & 1.35 & 1.62 & 0.05 \\
\hline 188 & 1.23 & 1.16 & 0.05 & 0.32 & 2.93 & 40.11 & 0.88 & 1.41 & 1.07 & 0.02 \\
\hline 190 & 1.25 & 1.16 & 0.06 & 0.2 & 4.7 & 47.46 & 0.9 & 1.45 & 2.57 & 0.12 \\
\hline 191 & 3.37 & 3.05 & 0.22 & 0.94 & 23.22 & 66.71 & 2.57 & 3.71 & 6.93 & 0.61 \\
\hline 193 & 1.80 & 1.47 & 0.21 & 0.2 & 21.47 & 117 & 1.15 & 1.94 & 8.28 & 0.78 \\
\hline \multicolumn{11}{|c|}{ Soil Temperature (Co) } \\
\hline 184 & 24.40 & 24.01 & 0.29 & 19.15 & 33.34 & 11.83 & 22.26 & 26.15 & 0.66 & -0.003 \\
\hline 186 & 23.57 & 22.80 & 0.32 & 19.42 & 33.34 & 13.61 & 20.87 & 25.54 & 0.79 & -0.003 \\
\hline 188 & 21.72 & 21.65 & 0.12 & 19.42 & 30.67 & 5.39 & 21.03 & 22.14 & 4.45 & 0.34 \\
\hline 190 & 22.15 & 21.86 & 0.10 & 20.38 & 25.56 & 4.45 & 21.38 & 22.89 & 0.76 & 0.004 \\
\hline 191 & 20.06 & 19.96 & 0.05 & 19.09 & 20.98 & 2.36 & 19.71 & 20.54 & 0.19 & -0.01 \\
\hline 193 & 20.04 & 19.34 & 0.20 & 16.32 & 26.09 & 10.33 & 18.66 & 20.58 & 1.30 & 0.01 \\
\hline \multicolumn{11}{|c|}{ Soil Moisture (\% volume) } \\
\hline 184 & 7.20 & 7.8 & 0.23 & 2.6 & 22.1 & 32.8 & 5.2 & 7.8 & 2.35 & 0.15 \\
\hline 186 & 5.54 & 6 & 0.18 & 2 & 17 & 32.8 & 4 & 6 & 2.35 & 0.15 \\
\hline 188 & 9 & 9 & 0.17 & 6 & 20 & 18.96 & 8 & 9.75 & 3.21 & 0.18 \\
\hline 190 & 8.64 & 9 & 0.12 & 6 & 12 & 13.78 & 8 & 9 & 0.47 & 0.002 \\
\hline 191 & 15.38 & 15 & 0.25 & 6 & 22 & 16.13 & 14 & 17 & -0.44 & 0.02 \\
\hline 193 & 10.94 & 11 & 0.19 & 6 & 16 & 17.48 & 10 & 12 & -0.02 & 0.002 \\
\hline
\end{tabular}

Med Median; SE Average standard error; Min Mínimum; Max Maximum; CV coefficient of variation (\%); Q1 first quartile; Q3 third quartile; Skewness coefficient of skewn; Kurt coefficient of kurtosis 
Table 3. Models and parameter estimates adjusted to the experimental variograms for soil $\mathrm{CO}_{2}$ emission, soil temperature, and soil moisture for the studied days in 2013 in soybean and 2014 in sugarcane.

\begin{tabular}{|c|c|c|c|c|c|c|c|}
\hline \multirow{3}{*}{ Julian Day } & Model & $C_{0}$ & $C_{0}+C_{1}$ & $a(\mathrm{~m})$ & SRS & $r^{2}$ & SDD \\
\hline & \multicolumn{7}{|c|}{ Soybean (2013) } \\
\hline & \multicolumn{7}{|c|}{ Soil $\mathrm{CO}_{2}$ emission } \\
\hline 323 & Sph & 1.50 & 2.90 & 8.41 & 0.43 & 0.81 & 0.52 \\
\hline 327 & Gau & 0.80 & 1.79 & 12.63 & 0.37 & 0.81 & 0.45 \\
\hline 330 & Exp & 0.24 & 0.62 & 11.01 & 0.02 & 0.78 & 0.39 \\
\hline 332 & Exp & 0.14 & 0.29 & 23.97 & $1.98 \mathrm{E}-03$ & 0.89 & 0.48 \\
\hline 337 & $\mathrm{Sph}$ & 0.29 & 0.61 & 21.31 & $5.40 \mathrm{E}-03$ & 0.93 & 0.48 \\
\hline 339 & Sph & 0.14 & 0.31 & 10.90 & $1.34 \mathrm{E}-03$ & 0.95 & 0.45 \\
\hline 344 & Exp & 0.47 & 0.82 & 27.00 & 0.02 & 0.79 & 0.57 \\
\hline \multicolumn{8}{|c|}{ Soil Temperature } \\
\hline 323 & Exp & 0.12 & 0.45 & 6.93 & $7.64 \mathrm{E}-03$ & 0.85 & 0.27 \\
\hline 327 & Exp & 0.06 & 0.14 & 9.57 & $1.12 \mathrm{E}-03$ & 0.60 & 0.43 \\
\hline 330 & Exp & 0.00 & 0.39 & 4.71 & 0.03 & 0.81 & 0.00 \\
\hline 332 & Sph & 0.28 & 0.60 & 29.95 & 0.01 & 0.88 & 0.47 \\
\hline 337 & Sph & 0.35 & 1.27 & 28.80 & 0.19 & 0.80 & 0.28 \\
\hline 339 & PNE & 0.28 & 0.28 & --- & --- & --- & 1.00 \\
\hline 344 & Sph & 0.06 & 0.14 & 13.95 & $5.17 \mathrm{E}-04$ & 0.90 & 0.43 \\
\hline \multicolumn{8}{|c|}{ Soil Moisture } \\
\hline 323 & Sph & 0.76 & 2.82 & 34.70 & 0.12 & 0.97 & 0.27 \\
\hline 327 & Exp & 0.29 & 2.91 & 37.80 & 0.39 & 0.93 & 0.10 \\
\hline 330 & Exp & 3.29 & 6.59 & 31.86 & 0.56 & 0.86 & 0.50 \\
\hline 332 & Sph & 0.65 & 2.76 & 2.19 & 0.33 & 0.86 & 0.24 \\
\hline 337 & Sph & 1.13 & 2.52 & 53.20 & 0.23 & 0.91 & 0.45 \\
\hline 339 & Gau & 1.13 & 1.59 & 9.02 & 0.03 & 0.83 & 0.71 \\
\hline 344 & Exp & 3.77 & 7.29 & 4.23 & 2.83 & 0.56 & 0.52 \\
\hline \multicolumn{8}{|c|}{ Sugarcane (2014) } \\
\hline \multicolumn{8}{|c|}{ Soil $\mathrm{CO}_{2}$ emission } \\
\hline 184 & Exp & 0.09600 & 0.28200 & 18.9 & $8.127 \mathrm{E}-04$ & 0.90 & 0.34 \\
\hline 186 & Exp & 0.09660 & 0.25020 & 20.7 & $6.176 \mathrm{E}-03$ & 0.45 & 0.39 \\
\hline 188 & Exp & 0.07040 & 0.21880 & 15.3 & $2.584 \mathrm{E}-03$ & 0.56 & 0.32 \\
\hline 190 & Exp & 0.06988 & 0.16570 & 27.3 & 2.191E-03 & 0.60 & 0.42 \\
\hline 191 & Sph & 0.44599 & 1.13400 & 15.4 & 0.0374 & 0.79 & 0.39 \\
\hline 193 & Exp & 0.24950 & 0.50900 & 21.6 & $2.888 \mathrm{E}-03$ & 0.84 & 0.49 \\
\hline \multicolumn{8}{|c|}{ Soil Temperature } \\
\hline 184 & Sph & 0.70000 & 10.21000 & 90.90 & 16 & 0.84 & 0.07 \\
\hline 186 & Gau & 0.90000 & 16.39000 & 96.82 & 13.3 & 0.95 & 0.05 \\
\hline 188 & Sph & 0.19500 & 0.71100 & 83.90 & 0.06 & 0.85 & 0.27 \\
\hline 190 & Sph & 0.00100 & 0.94200 & 33.80 & 0.08 & 0.89 & 0.001 \\
\hline 191 & Sph & 0.00030 & 0.24060 & 32.70 & $1.824 \mathrm{E}-03$ & 0.95 & 0.001 \\
\hline 193 & Exp & 0.27000 & 5.32800 & 23.40 & 0.61 & 0.96 & 0.05 \\
\hline \multicolumn{8}{|c|}{ Soil Moisture } \\
\hline 184 & $\mathrm{NE}$ & 2.52764 & 2.52764 & --- & --- & --- & --- \\
\hline 186 & $\mathrm{NE}$ & 1.64900 & 1.64900 & --- & --- & --- & --- \\
\hline 188 & Exp & 0.56600 & 3.24100 & 19.8 & 1.09 & 0.59 & 0.17 \\
\hline 190 & Gau & 1.05100 & 1.85460 & 117.86 & 0.138 & 0.90 & 0.57 \\
\hline 191 & Sph & 1.72454 & 4.82053 & 16.98 & 1.29 & 0.66 & 0.36 \\
\hline 193 & Exp & 1.89800 & 3.79700 & 64.8 & 0.488 & 0.80 & 0.50 \\
\hline
\end{tabular}

SDD Spatial dependence degree $=C_{0} /\left(C_{0}+C_{1}\right)$, Strong for the values lower than 0.25 ; moderate for the values between 0.25 e 0.75 ; weak for the values higher than 0.75 (Cambardella et al., 1994); SRS sum of residue squares; Exp exponential; Sph spherical; NE = nugget effect; Gau Gaussian.

For the soybean experiment, the larger coefficient of variation values (CV) for $\mathrm{FCO}_{2}$ were observed in the first days of evaluation found on days 323, 327 and 330 (52.85; 64.05 and 53.73, respectively) also presented a high skewness values $(1.55,2.19$ and 1.04, respectively) in addition the day 337 also presented a high skewness value equal to 1.98. For the sugarcane experiment, the highest $\mathrm{FCO}_{2} \mathrm{VC}$ values were observed on days 186, 190 and 191 (52.28; 47.46 and 66.71, respectively) the days 190, 191 and 193 presented higher skewness values (2.57, 6.93 and 8.28 respectively) (Table 2 ). These 
results, allied to the fact that the similarity between the average and median values indicate data distribution close to a normal distribution for the two experiments. The $\mathrm{FCO}_{2}$ coefficients of kurtosis were close to zero for all the evaluated days. In wheat cultivation area, in Ottawa, Canada, were observed CV values between 25 to $69 \%$ in a study that took into account the FCO2 spatial variability (Rochette; Desjardins \& Pattey, 1991).

In eutrophic Red Latosol soybean cultivation (conventional system), in Jaboticabal city, São Paulo (Brazil), the $\mathrm{FCO}_{2}$ values ranged from $0.94 \mu \mathrm{mol} \mathrm{m} \mathrm{m}^{-2} \mathrm{~s}^{-1}$ to 1.41 $\mu \mathrm{mol} \mathrm{m} \mathrm{m}^{-2} \mathrm{~s}^{-1}$ with flow increase observed after rains which add up $1.4 \mathrm{~mm}$ (La Scala et al., 2003), lower values than those observed in the recent study. Furthermore, the authors observed CV values between 20.3 and $28.7 \%$, also, lower than those observed in the recent study. In a study of the spatial variability of microbiological attributes of a Luvisol cultured with wheat, Piotrowska \& Dlugosz (2012) related the skewness coefficient values, for $\mathrm{FCO}_{2}$, of 1.15 and 1.55 and kurtosis coefficient values of 2.78 and 4.31, similar values of those observed in this study. Teixeira et al. (2011), evaluating the diurnal variability of $\mathrm{CO}_{2}$ emissions in cultivated corn area in Jaboticabal city (SP, Brazil) found asymmetry and kurtosis coefficients ranging from 0.72 to 1.09 and 0.12 to 1.10 , respectively, similar to those observed in the present study.

In soybean experiment, the soil temperature (Ts) average values presented a fluctuation of $3.44{ }^{\circ} \mathrm{C}$, staying between 25.68 ${ }^{\circ} \mathrm{C}$ (day 327) and $29.08{ }^{\circ} \mathrm{C}$ (day 339), the soil moisture (Ms), the values were between 11.53 and $23.00 \%$ for days 339 and 323, respectively (Table 2). For the sugarcane experiment the Ts average values presented a fluctuation of $4.36{ }^{\circ} \mathrm{C}$, staying between 20.04 ${ }^{\circ} \mathrm{C}$ (day 193) and $24,40{ }^{\circ} \mathrm{C}$ (day 184), the Ms, the values were between $5.54 \%$ and $15.38 \%$ for 186 and 191 days, respectively (Table 2).

According to the classification criteria of the coefficient of variation proposed by Warrick \& Nielsen (1980) for the classification of spatial variability of soil attributes in soybean, may be regarded as having low variability ( $C V<12 \%)$ The observed values of Ts and Ms for some of the days (323, 327, 332 and 339). For the remaining days (330, 337 and 344 ), Ms was considered moderate (12\% $<\mathrm{CV}<24 \%$ ). For $\mathrm{FCO}_{2}$, in all the evaluated days the CV was classified as high (CV > 24\%), presenting a large spatial variation and justifying, this way, the use of geostatistics in an attempt of modeling the spatial dependence of this attribute. In the sugarcane experiment no value can be considered of low variability ( $\mathrm{CV}<12 \%)$ for the $\mathrm{Ms}$, but, in temperature almost every day $(184,188,190$, $191,193)$ are of low variability. For the days (188, 190, 191 and 193), Ms was considered moderate $(12 \%<\mathrm{VC}<24 \%)$ and for the Ts the day (186). The Ms was considered high (CV > $24 \%$ ) for the first days (184 and 186). For $\mathrm{FCO}_{2}$ in all evaluated days the $\mathrm{CV}$ was classified as high ( $\mathrm{CV}>24 \%$ ) such as the soybean, presenting a large spatial variation and justifying, therefore, the geostatistics use in an attempt to model the spatial dependence of this attribute.

According to Gonçalves et al. (2001), despite the normal distribution is not a precondition for the geostatistical analysis, the data should not present frequency distributions with very long tails, so the difference between the average and the median should be small because the variogram is 
strongly influenced by positive asymmetric distributions where few values can contribute to the increase of the semivariance (Webster and Oliver, 2009). The differences between the average and the median of soil $\mathrm{CO}_{2}$ emission (Table 2), compared with the soil temperature and moisture, indicated a slight positive asymmetric distribution of data, so, the FCO2 average values were influenced by high emission values. For Ts and Ms data, the average and median values were similar. Despite the slight asymmetry, previously to the geostatistical analysis execution, was not applied any original data transformation for the normalizing of the asymmetry of frequency of its distribution, being this procedure often used for the spatial description of this variable (Rochette et al, 1991; Pringle and Lark, 2006; Kosugi et al., 2007; Panosso et al., 2009a; Panosso et al., 2009b; Herbst et al., 2010).

In soybean experiment, the models adjusted to the $\mathrm{FCO}_{2}$ experimental variograms were spherical to the days 323, 337 and 339, Gaussian for the day 327 and exponential for the days 330, 332 and 344. For the sugarcane experiment the models adjusted to the $\mathrm{FCO}_{2}$ experimental variograms were, mostly, exponential for days 184.186, 188, 190 and 193, spherical for the day 191 according to the cross-validation analysis, used for the model's selection (Table 3 and Figures 1 and 2). These results corroborate several studies that present spherical models adjustments to the FCO2 experimental variograms (Dasselaar et al., 1998; Cardellini et al., 2003; Lewicki et al., 2005; Konda et al., 2008; Brito et al., 2010; Herbst et al., 2010; Teixeira et al., 2011), however, other studies report the exponential model adjustment (La Sacala et al., 2000b; Stoyan et al., 2000; Ohashi \& Gyokusen, 2007; Panosso et al., 2009a). Most of $\mathrm{FCO}_{2}$ models presented the coefficient of determination values, expressed by $r 2$ values higher than $75 \%$, indicating good adjustments to the experimental variogram models (Table 3). The mathematical models describe the variability in different ways, being responsible for the existing features in spatial patterns (Figures 1 and 2) of each variable. According to Isaaks \& Srivastava (1989), the exponential models are better adjusted to erratic behavior phenomena in small scale, while the spherical models describe variables with high spatial continuity, or less erratic in a small distance, in turn, the Gaussian model is adopted for regular and continuous phenomena.

For the soybean experiment, the models adjusted to the Ts variograms were: exponential for the days 323, 327 and 330; spherical for days 332, 337 and 344; and lack of spatial variability structure (NE - nugget effect) for the day 339 (Table 3 and Figures 1 and 2). For the Ms, the adjusted models were spherical in the days 323, 332 and 33; exponential in the days 327, 330 and 344; and Gaussian in the day 339. For the sugarcane experiment, the models adjusted to the Ts variograms were: spherical for the days 184, 188, 190 and 191; Gaussian for the day 186; and exponential for the day 193 (Table 3 and Figures 3 and 4). For the Ms the adjusted models were a lack of spatial variability structure for the days 184 and 186; exponential for the days 188 and 193; Gaussian for the day 190; and spherical for the day 191. Panosso et al. (2009a) studying the spatial variability of soil $\mathrm{CO}_{2}$ emission, soil temperature, and soil moisture in areas of green and burned sugarcane, they observed alternations between models adjusted to the experimental variograms similar to those observed in the present study. 
Soil $\mathrm{CO}_{2}$ emission $\left(\mu \mathrm{mol} \mathrm{m}^{-2} \mathrm{~s}^{-1}\right)$
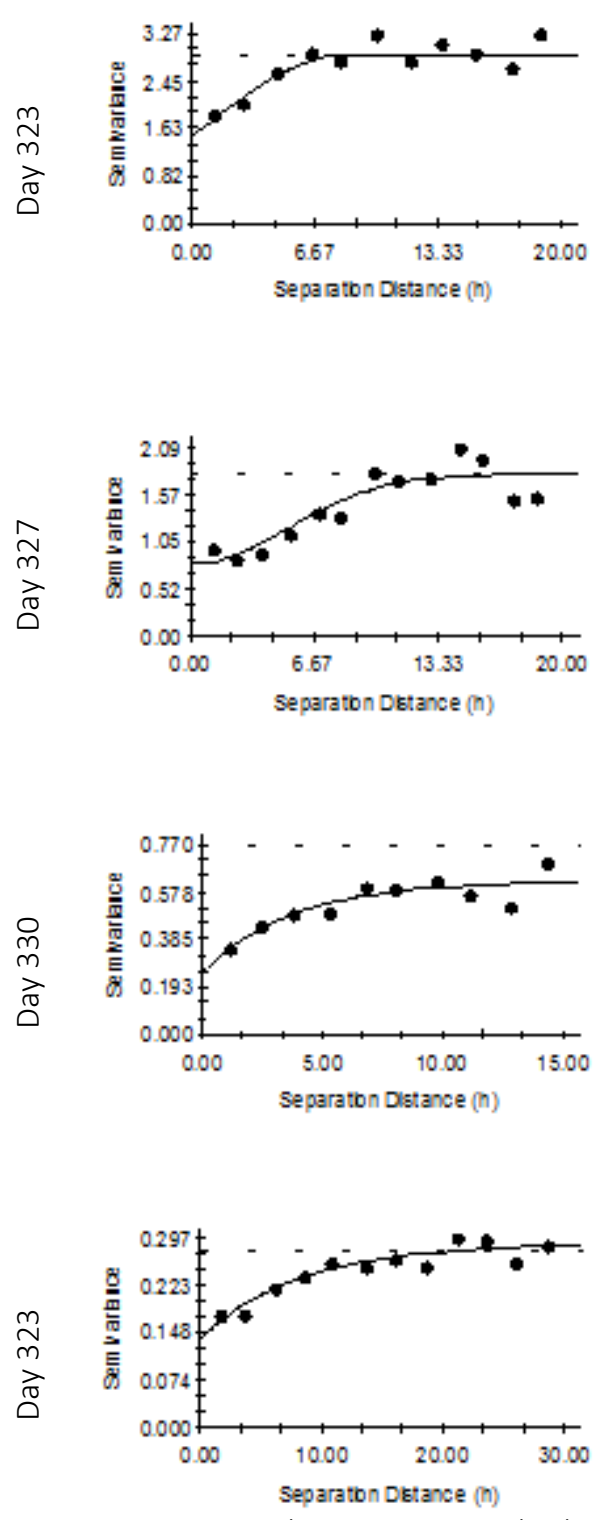

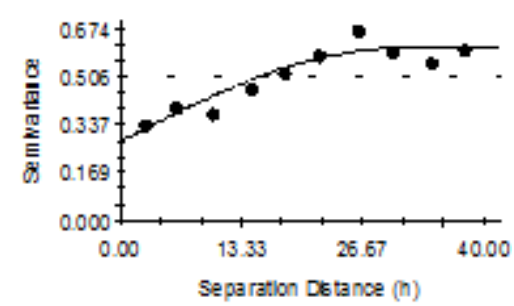

Soil Moisture (\%volume)
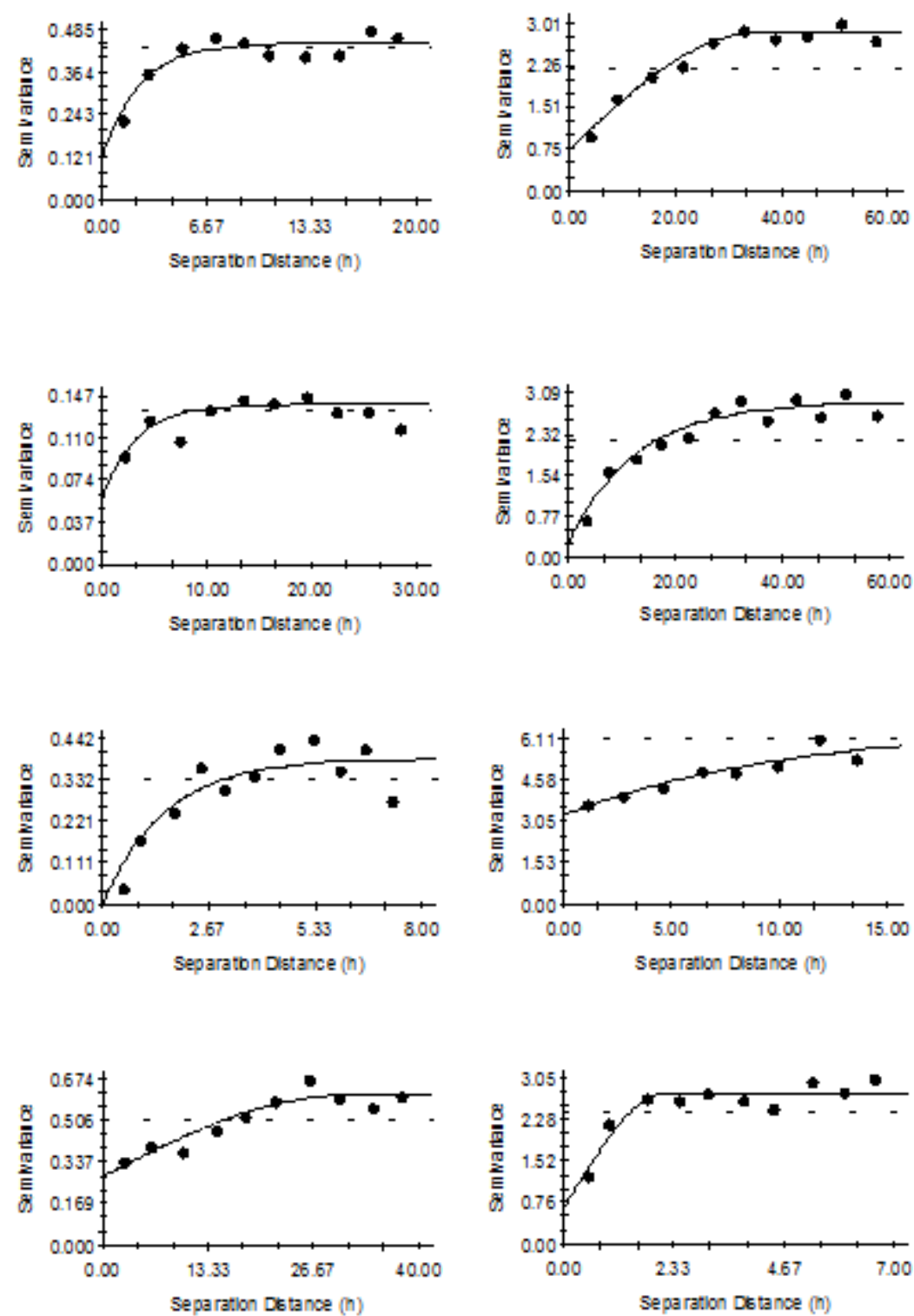

Figura 1. Experimental variograms and adjusted models for soil $\mathrm{CO}_{2}$ emission, soil temperature, and soil moisture on days $323,327,330$ e 332 in soybean.

For the soybean area, the spatial dependence degree (SDD) was classified as moderate for all the studied variables in the evaluation days, characterized by the relation $0.25<$ $\mathrm{CO} /(\mathrm{CO}+\mathrm{C} 1)<0.75$ (Cambardella et al., 1994), except for the Ts in the day 330 and $\mathrm{Ms}$ in the days 327 and 332 which presented SDD classified as strong (> 0.25) (Table 3), indicating a good estimate of semivariance in small distances. For the sugarcane area, the spatial dependence degree (SDD) was classified as moderate to all studied variables in the evaluation days, characterized by the relation $0.25<\mathrm{CO} /(\mathrm{CO}+\mathrm{C} 1)<0,75$ (Cambardella et al., 1994), except for Ts in the days 184, 186, 190, 191 and 193 and Ms in the day 188 which presented SDD classified as strong (>0.25) (Table 3). Studies in different 
cultures and soil types reported the weak or moderate degree of FCO2 spatial dependence (La Scala et al., 2000b; Stoyan et al., 2000; Ishizuka et al., 2005; Panosso et al., 2009a). Herbst et al. (2009), evaluating the $\mathrm{FCO}_{2}$ in a bare soil, determined structures with dependencies ranging from weak to strong.

For soybean data, the ranges (a) of the fitted models adjusted to the $\mathrm{FCO}_{2}$ variograms present large variations during the evaluation days for the studied years (Figure 3). The lower a value was $8.41 \mathrm{~m}$ for the day 323 and the higher was 27 $\mathrm{m}$ for the day 344. Changes in $\mathrm{FCO}_{2}$ a has been noted among the year's season (Ohashi \& Gyokusen, 2007), months (Stoyan et al., 2000), after rainfall (La Sacala et al., 2000b), or even according to the size of the sample grid (Rayment \& Jarvis, 2000; Konda et al., 2008). The range values provide information regarding the spatial distribution heterogeneity in relation to the studied variables (Trangmar et al., 1985), thus the higher range value of the spatial variability of structures of a certain variable, indicates a more homogeneous distribution of this variable for the day in question. For the sugarcane, the ranges of the models adjusted to the $\mathrm{FCO}_{2}$ variograms present large variations during the evaluation days for the studied years, although had a lower variation comparing to the soybean data. The lower a was $15.3 \mathrm{~m}$ for the day 188 and the higher value was $27.3 \mathrm{~m}$ for the day 190.
Soil $\mathrm{CO}_{2}$ emission $\left(\mu \mathrm{mol} \mathrm{m} \mathrm{m}^{-2} \mathrm{~s}^{-1}\right)$
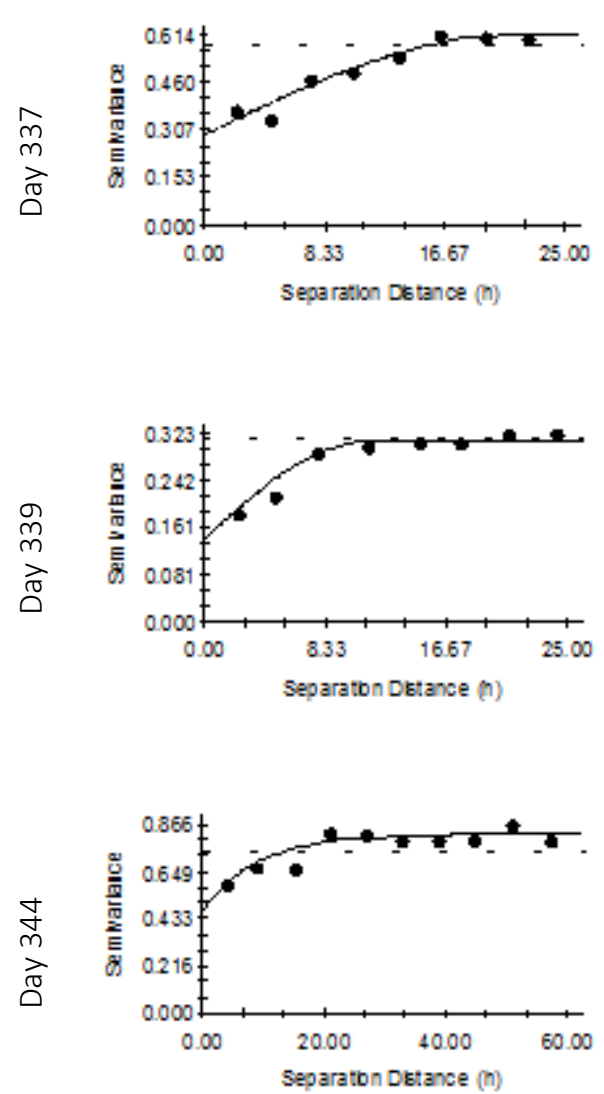

Soil Temperature $\left({ }^{\circ} \mathrm{C}\right)$
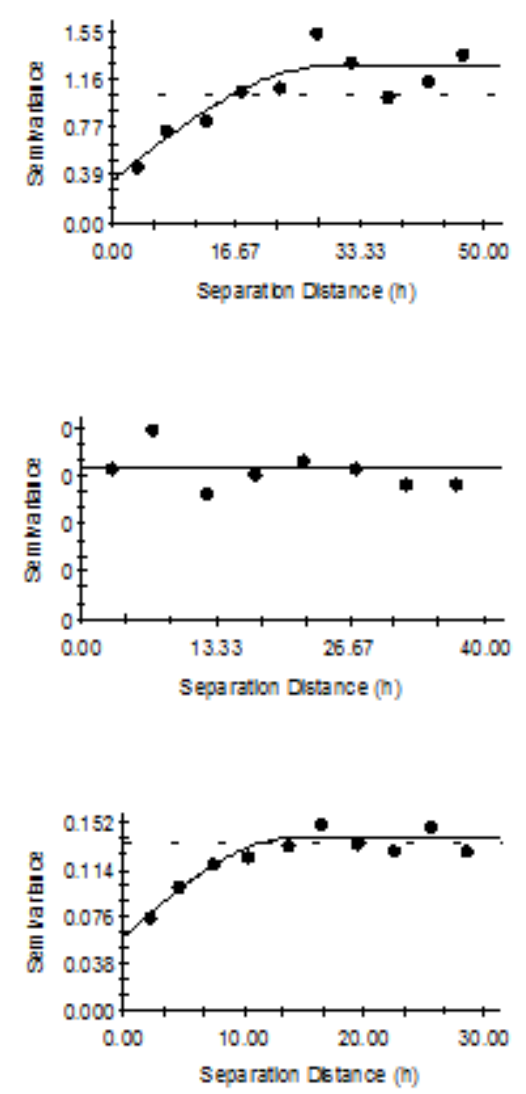

Soil Moisture (\%volume)
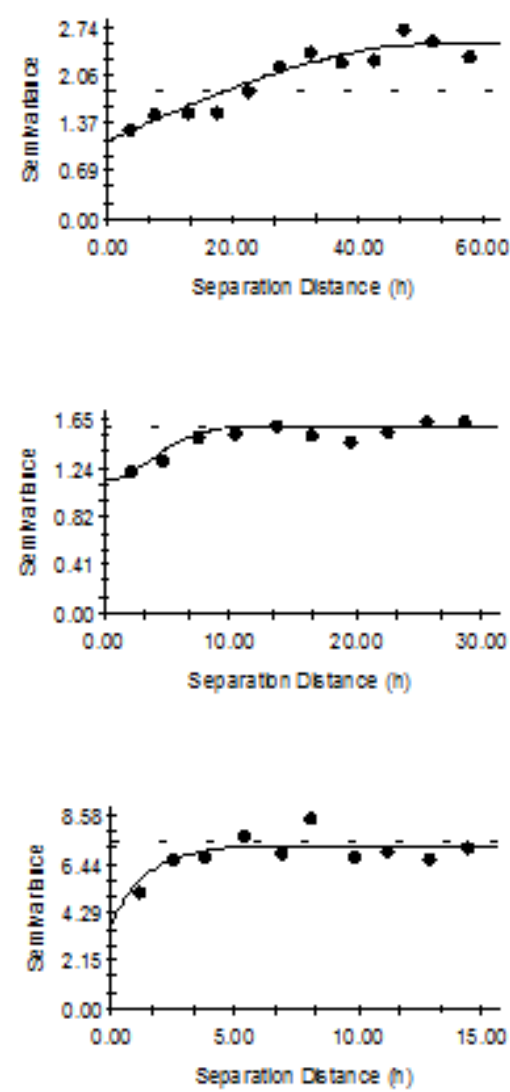

Figure 2. Experimental variograms and adjusted models for soil $\mathrm{CO}_{2}$, soil temperature and soil moisture on days 337 , 339 e 344 in soybean area. 

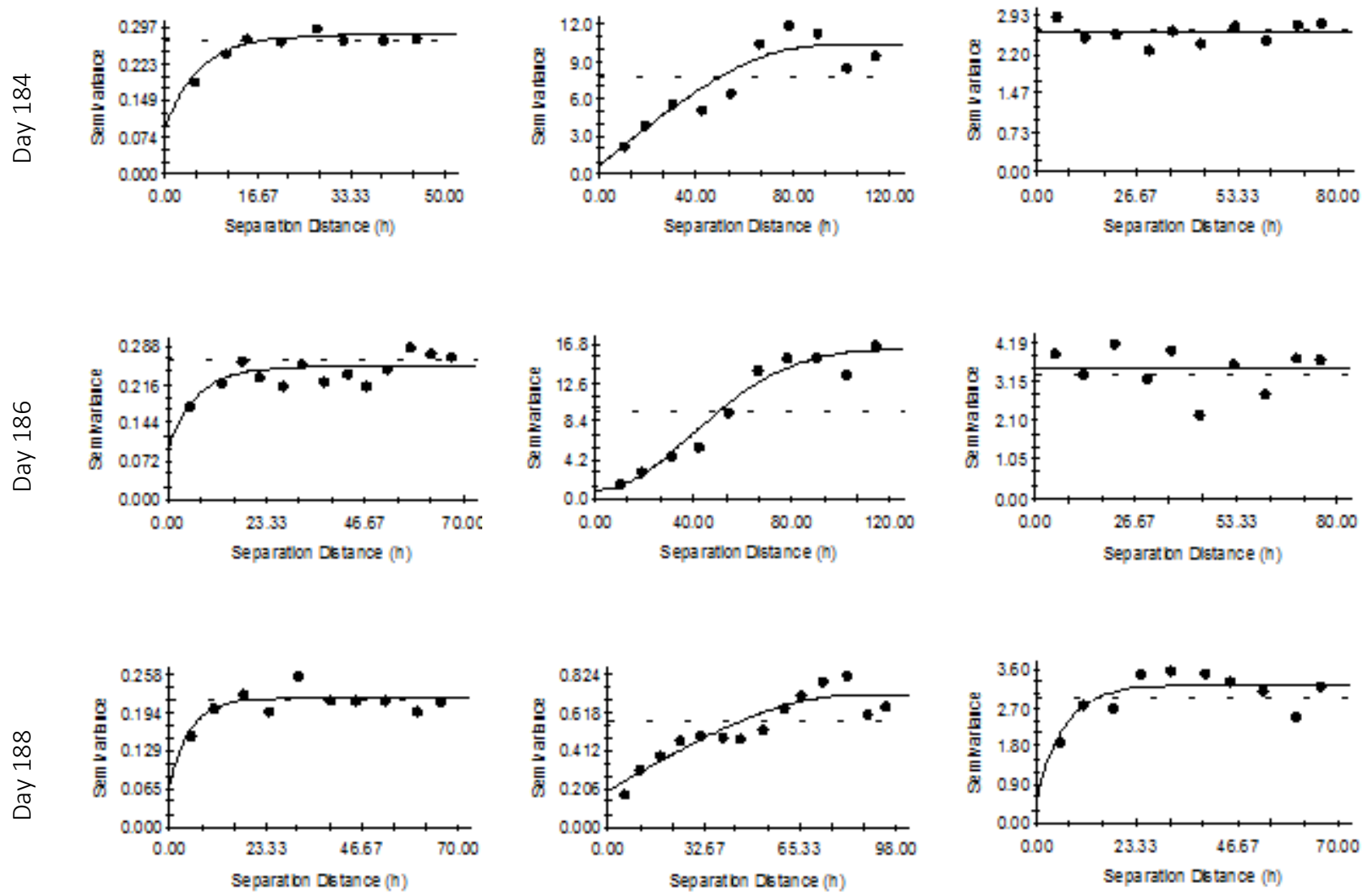

Figure 3. Experimental variograms and adjusted models for soil $\mathrm{CO}_{2}$ emission, soil temperature and soil moisture on days 184,186 and 188 in sugarcane culture.

For the Ts of soybean, the experiment was noted daily variations of the range of the adjusted models (Table 3 ), being the range values ranged from the lack of variability structure to $29.95 \mathrm{~m}$. The range value model adjusted to the Ms variogram also presented large variation along the studied periods. The lower value was $2.19 \mathrm{~m}$ being observed for the day 332 and the higher value was $53.20 \mathrm{~m}$ being observed for the day 332. For sugarcane Ts were observed daily variations of the range of the adjusted models (Table 3 ) the range values of the variability ranged from 23.40 to $96.82 \mathrm{~m}$ variability. The range value model adjusted to the Ms variogram also presented large variation along the studied periods since the lack of variability structure until $117.86 \mathrm{~m}$. The lower value was $16.98 \mathrm{~m}$ being observed for the day 191, and the higher value was $117.86 \mathrm{~m}$ being observed for the day 190.

The model adjusted to the experimental $\mathrm{FCO}_{2}$, Ts and Ms variograms were used to obtain the estimation of these variables values for nonsampled locations through the interpolation of ordinary kriging process, generating, this way, the spatial patterns maps (Figures 5 to 8). As mentioned earlier, the mathematical models describe distinctly the patterns of the spatial variability of the studied attributes, being, so, responsible for the difference of the spatial continuity maps of the same variable. The $\mathrm{FCO}_{2}$ spatial variability patterns cannot be considered constant throughout the study period, for the soybean and sugarcane areas. 
Soil $\mathrm{CO}_{2}$ emission $\left(\mu \mathrm{mol} \mathrm{m}^{-2} \mathrm{~s}^{-1}\right)$
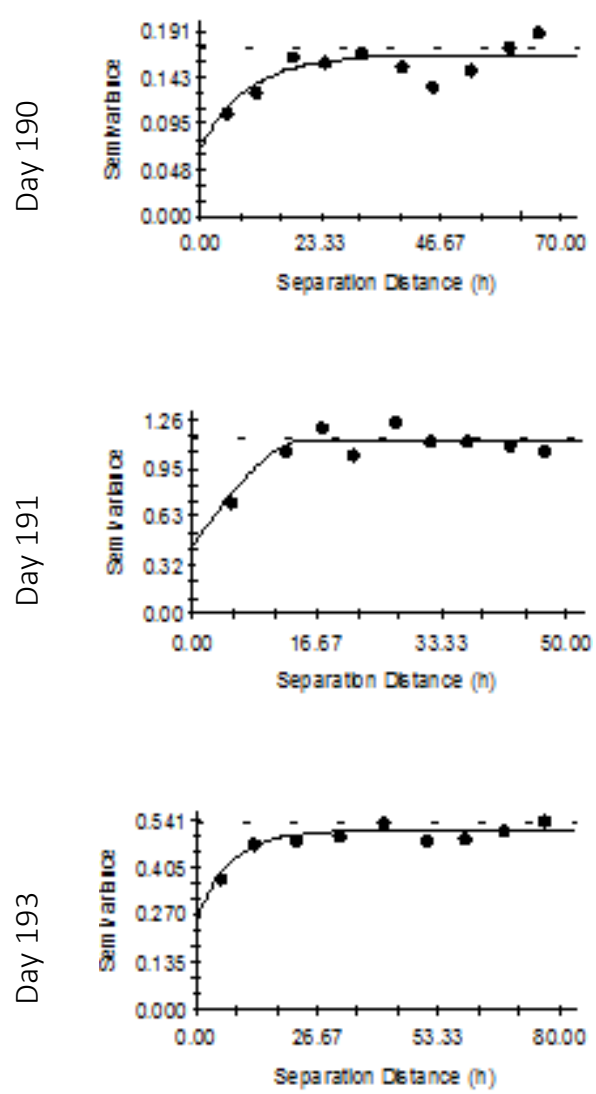

Soil Temperature $\left({ }^{\circ} \mathrm{C}\right)$
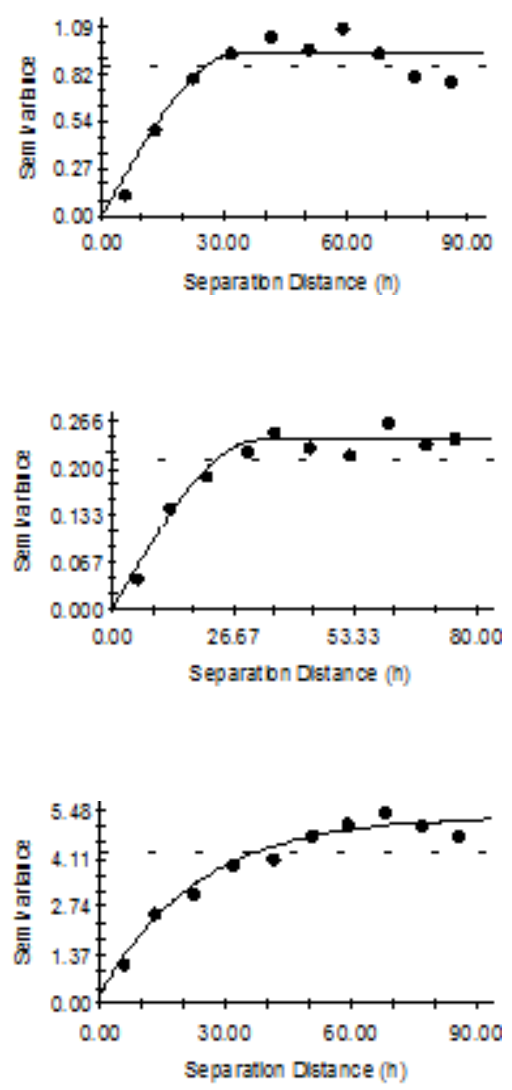

Soil Moisture (\%volume)
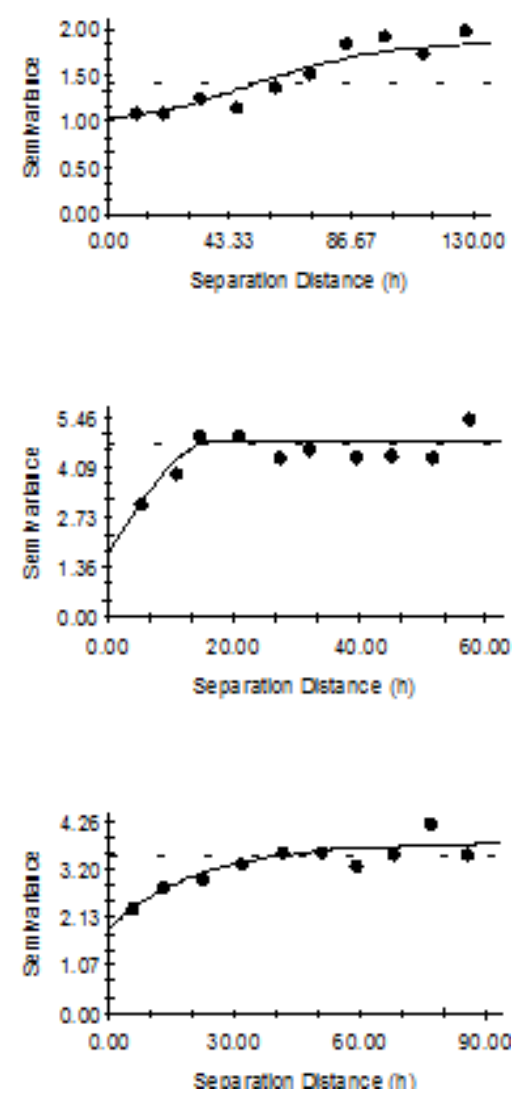

Figure 4. Experimental variograms and adjusted models for soil $\mathrm{CO}_{2}$ emission, soil temperature and soil moisture on days 190, 191 and 193 in the sugarcane area.

For the soybean area, the higher FCO2 variation amplitudes were observed for the days 323 and 327 , with the values between 2.0 to $6.2 \mu \mathrm{mol} \mathrm{m} \mathrm{m}^{-2} \mathrm{~s}^{-1}$ and 0.6 to $5.6 \mu \mathrm{mol} \mathrm{m} \mathrm{m}^{-2}$ $\mathrm{s}^{-1}$, respectively (Figures 1 and 2 ). These observations may be associated with the rainfall of $51.6 \mathrm{~mm}$ occurred in the day 322 , before the beginning of the experiment. The spatial patterns of $\mathrm{FCO}_{2}$ for the days 339 and 344 were similar, as to its continuity. The spatial patterns maps represent the agricultural studied areas, where were added colors according to the amount of soil $\mathrm{CO}_{2}$ emission, soil temperature, and soil moisture, being the colors closer to red with higher amounts, the green color as an intermediary and bluish tones as places of low amounts of the variable in question.
The Ms spatial patterns maps presented the higher moisture values for these days when compared to other evaluation, besides, the days 323 and 327 presented greater spatial continuity. The higher moisture region can be identified to the left of the spatial variation patterns for most of the evaluated days, with an observed moisture accumulation in the lower area region (lower elevation region), quite characteristic in the day 337 (Figure 8). The results indicate that the non-temporal uniformity of $\mathrm{FCO}_{2}$ and $\mathrm{Ms}$ variability patterns may be associated with the occurrence of rainfall events throughout the study period, with small rainfall occurred in the days 325,326 , $329,330,336$, totaling $21.6 \mathrm{~mm}$ and the higher event occurred in the days 340, 341 and 343, totaling $81.8 \mathrm{~mm}$, being this the last event, 
responsible for increasing values of the MS and, consequently of $\mathrm{FCO}_{2}$ observed in the day 344 (Figure 2).

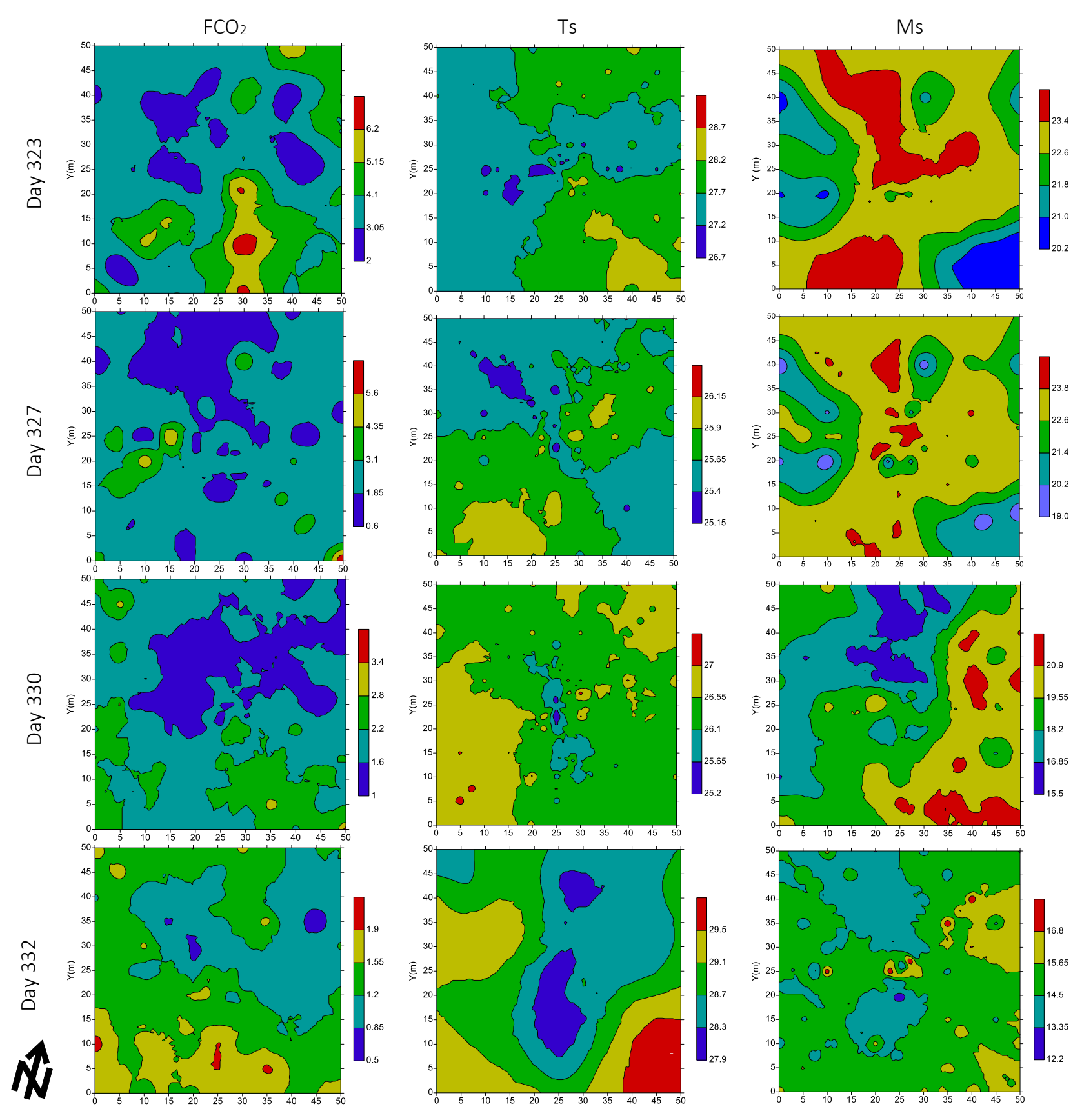

Figure 5 Spatial pattern maps of the $\mathrm{CO}_{2}$ emission $\left(\mu \mathrm{mol} \mathrm{m} \mathrm{m}^{-2} \mathrm{~s}^{-1}\right.$ ), soil temperature $\left({ }^{\circ} \mathrm{C}\right)$ and soil moisture $(\%$ volum) in the days $323,327,330$ and 332 in soybean. 
$\mathrm{FCO}_{2}$
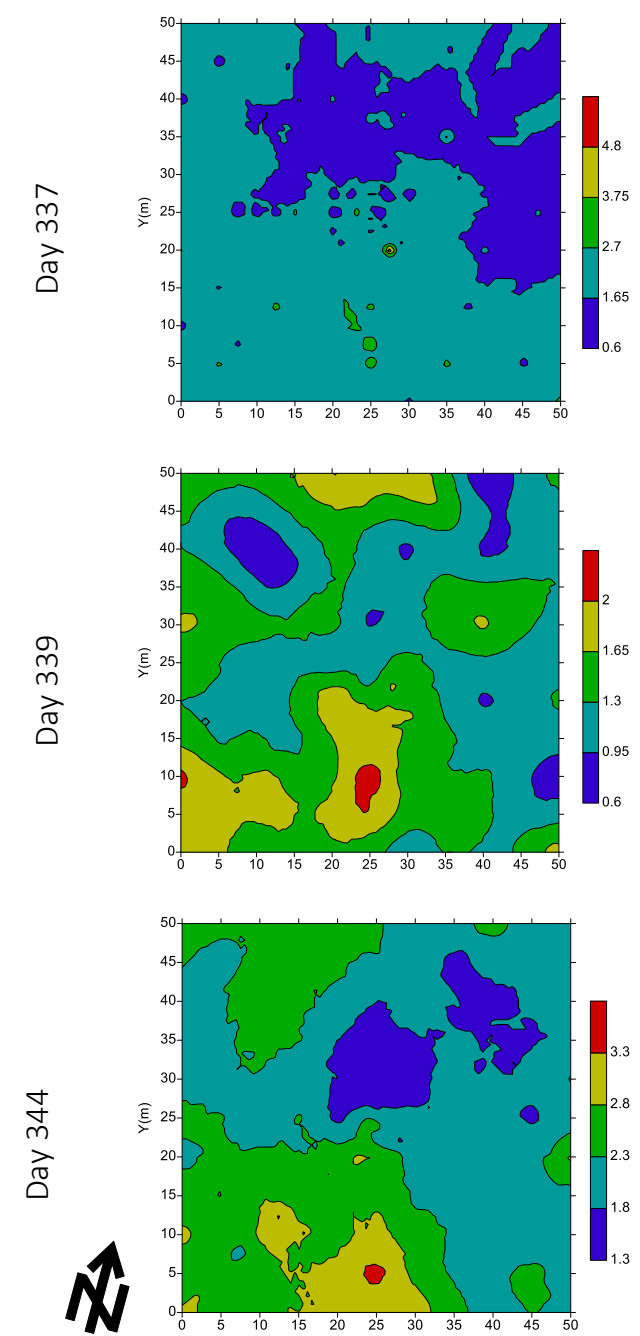

Ts
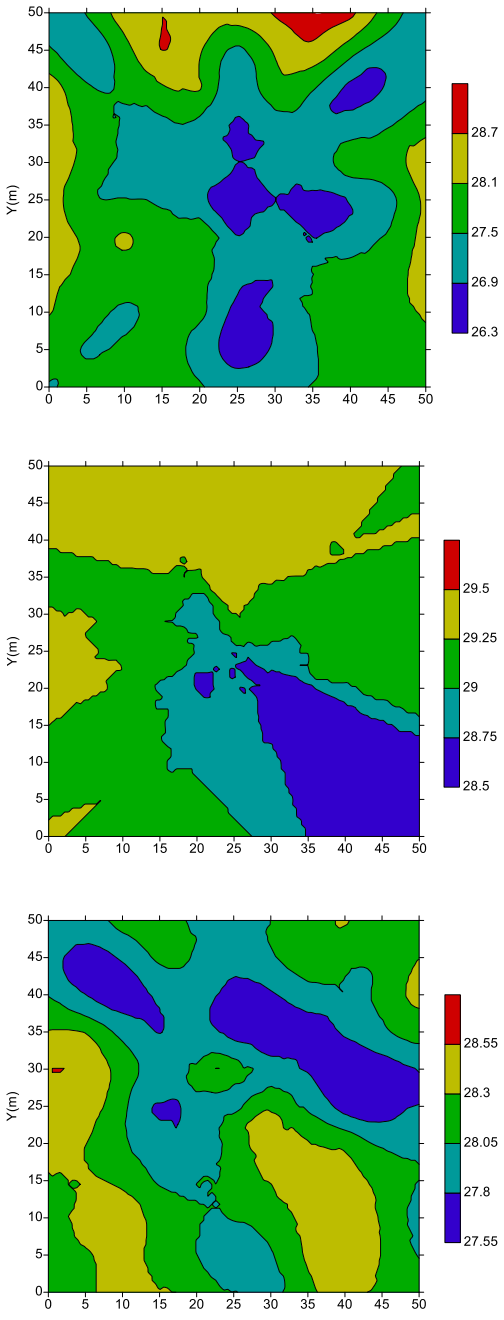

Ms
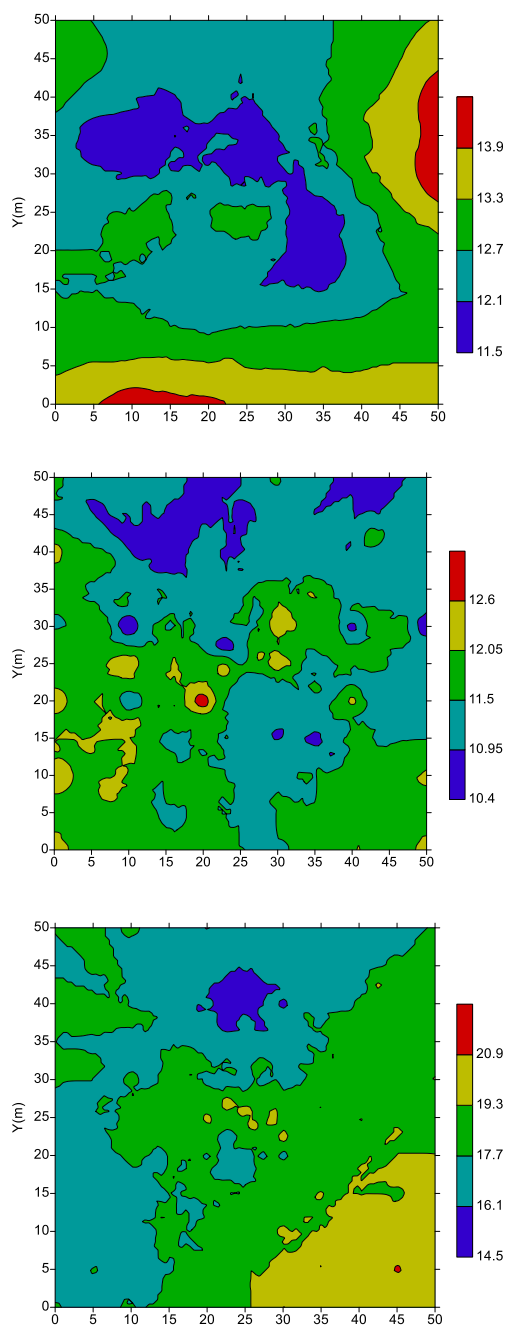

Figure 6. Spatial pattern maps of the $\mathrm{CO}_{2}$ emission $\left(\mu \mathrm{mol} \mathrm{m} \mathrm{m}^{-2} \mathrm{~s}^{-1}\right)$, soil temperature $\left({ }^{\circ} \mathrm{C}\right)$ and soil moisture $(\%$ volume) in the days 337, 339 and 344 in soybean. 
$\mathrm{FCO}_{2}$
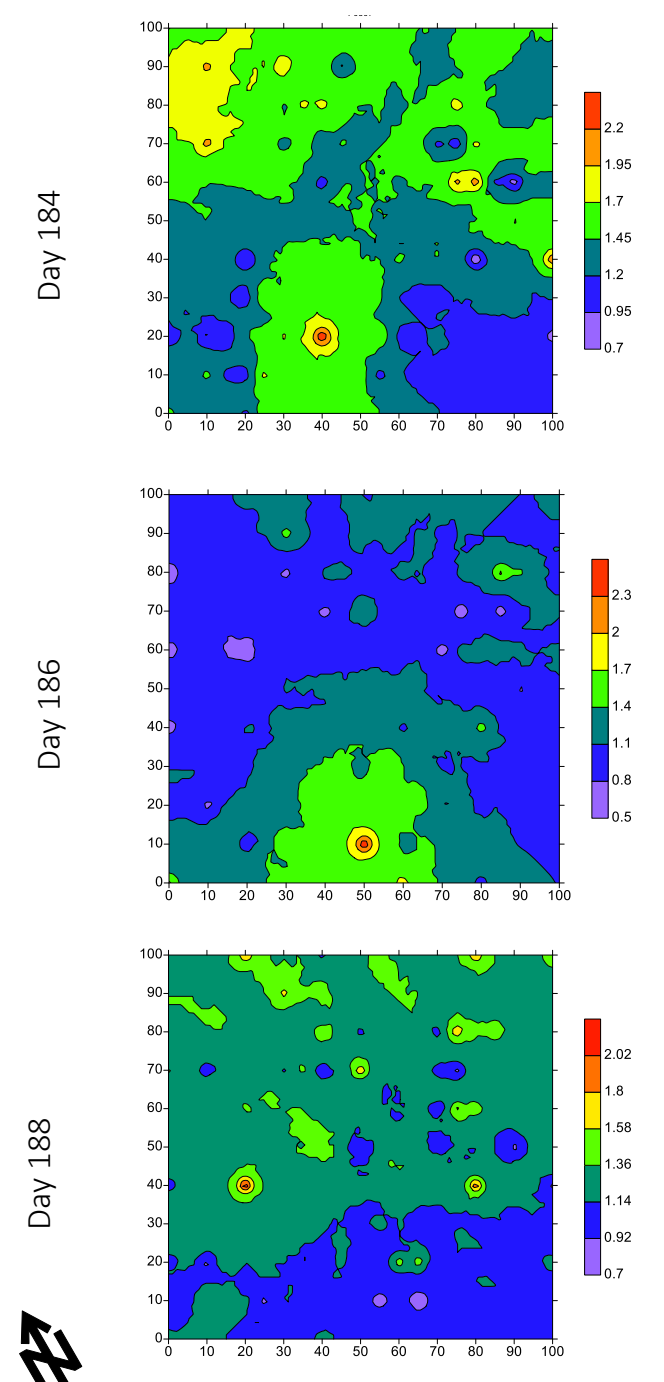

Ts
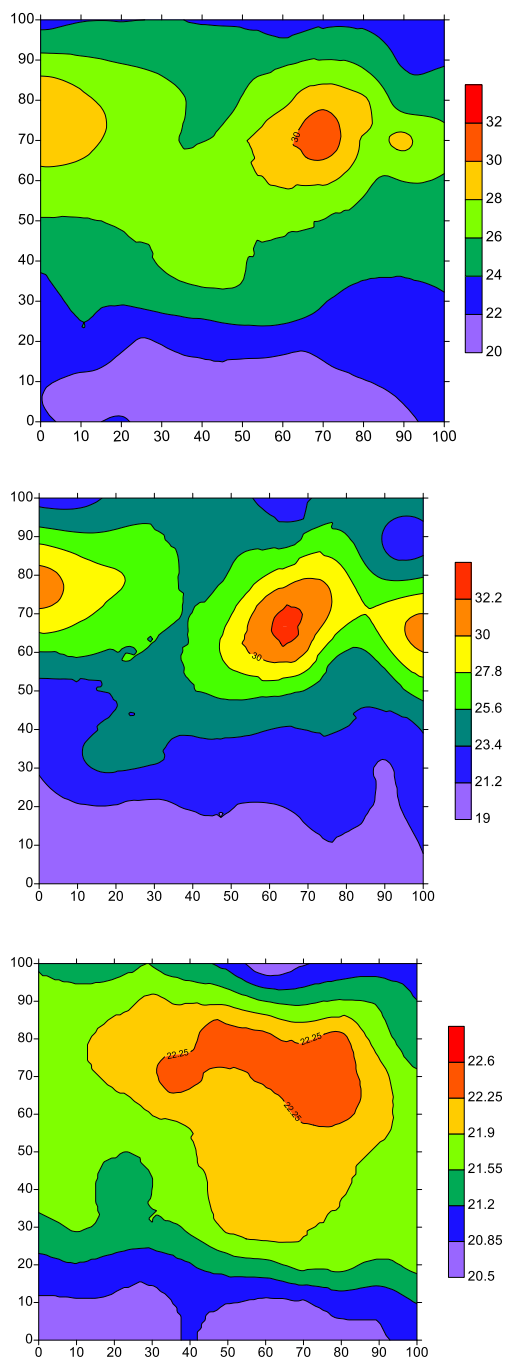

Ms
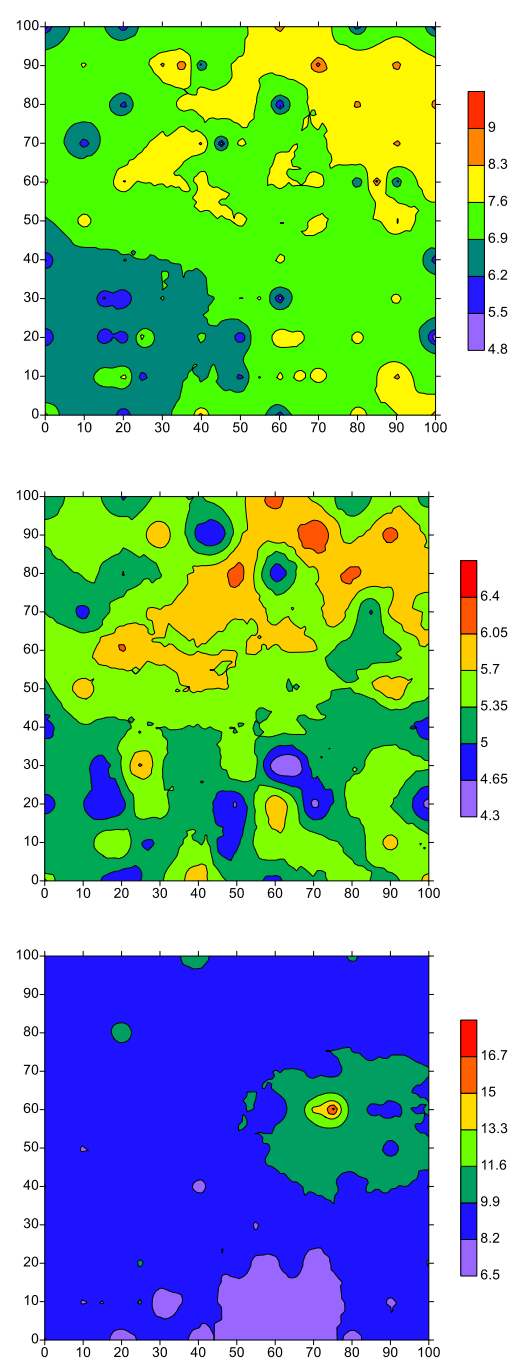

Figure 7 Spatial pattern maps of the $\mathrm{CO}_{2}$ emission $\left(\mu \mathrm{mol} \mathrm{m} \mathrm{m}^{-2} \mathrm{~s}^{-1}\right)$, soil temperature $\left({ }^{\circ} \mathrm{C}\right)$ and soil moisture $(\%$ volume) in the days 184, 186 and 188 in sugarcane. 
$\mathrm{FCO}_{2}$
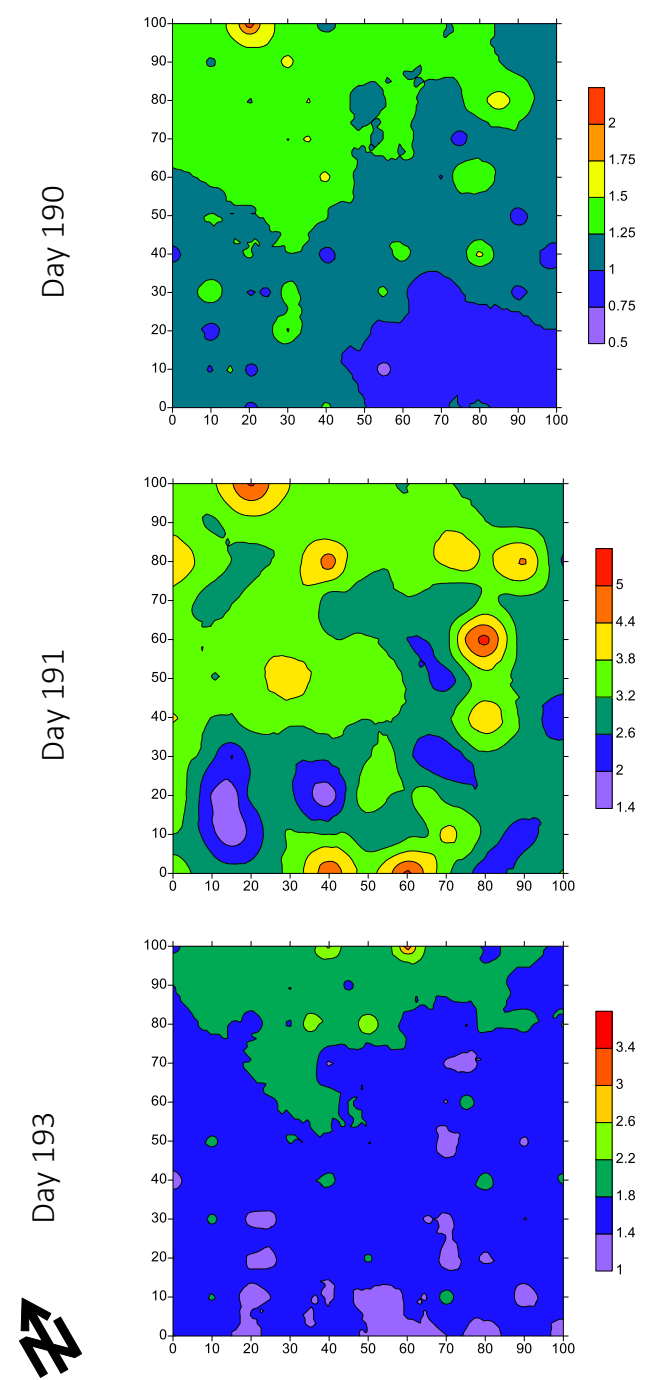

Ts
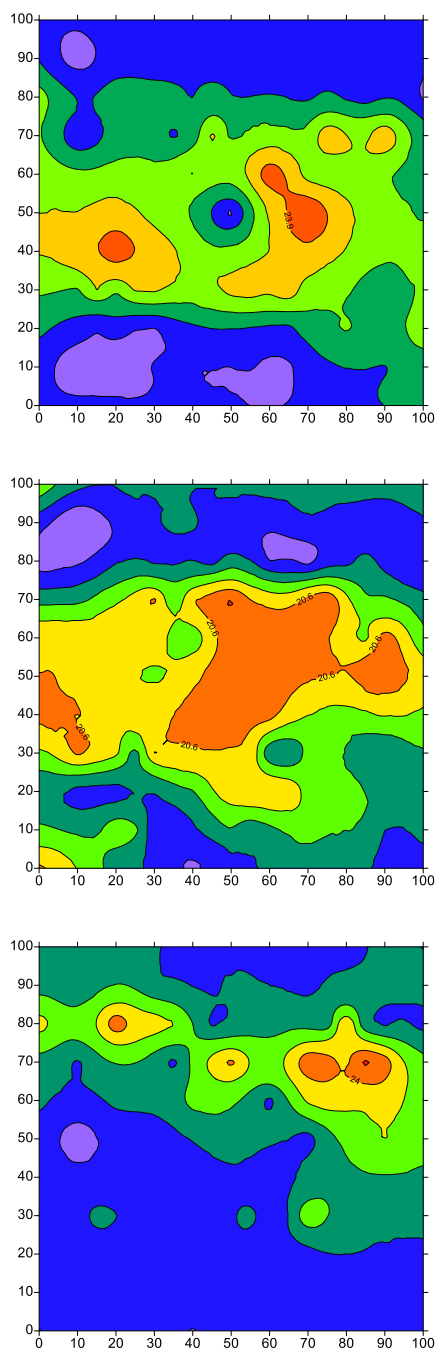

Ms
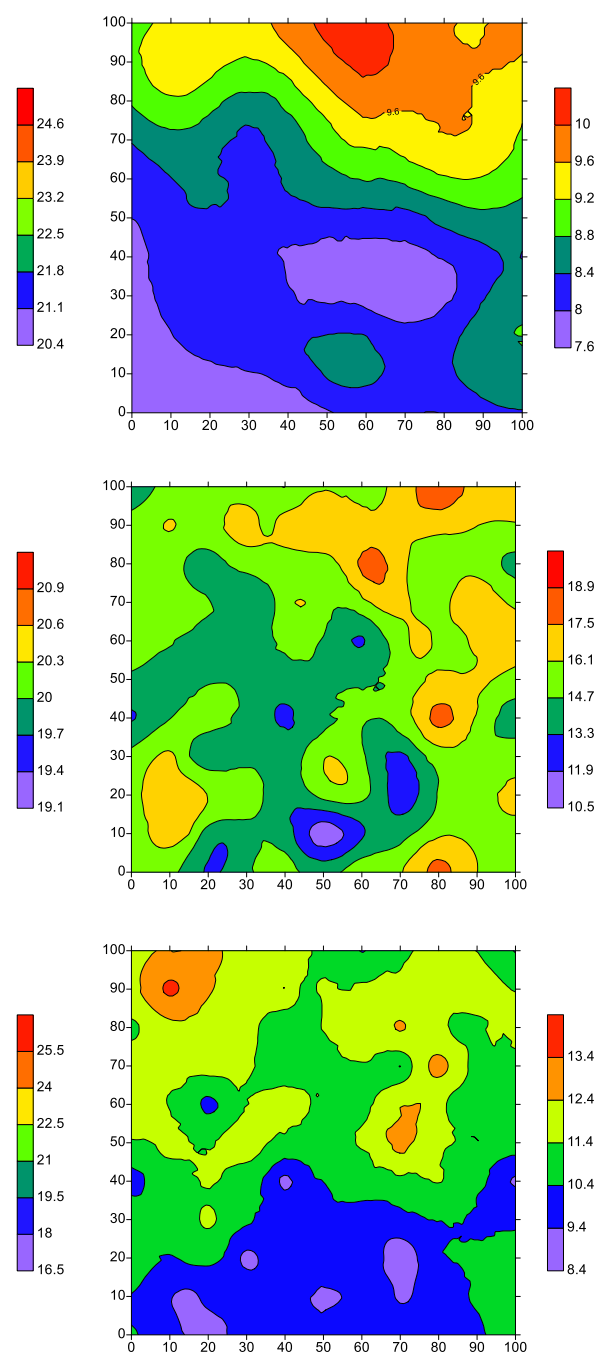

Figure 8. Spatial pattern maps of the $\mathrm{CO}_{2}$ emission ( $\left.\mu \mathrm{mol} \mathrm{m}^{-2} \mathrm{~s}^{-1}\right)$, soil temperature $\left({ }^{\circ} \mathrm{C}\right)$ and soil moisture $(\%$ volume) in the days 190, 191 and 193 in sugarcane area. 
For the sugarcane area, the variogram is presented in Figures 3 and 4, the higher FCO2 and Ms variation amplitudes were observed for the days 191, and 193 with values ranging from 1.4 to $5.0 \mu \mathrm{mol} \mathrm{m}-2 \mathrm{~s}^{-1}$ and 1.0 to 3.4 umol $\mathrm{m}^{-2} \mathrm{~s}^{-1}$, respectively (Figure 4). The spatial patterns maps of $\mathrm{FCO}_{2}$ present little continuity, similar to that observed in the soybean area, however, the day 191, presented the higher $\mathrm{FCO}_{2}$ continuity for the studied period. The $\mathrm{sH}$ spatial patterns maps presented the higher moisture values for the day 191, when compared to other evaluations, besides that, the higher spatial continuity of soil moisture maps was observed from 190.

The Ts spatial patterns maps for the soybean area indicated a higher spatial continuity in the days 332 to 344 (Figures 5 and 6), a period of lower soil moisture observed during the experiment, with less pronounced spatial patterns variations, along the studied days studied, and the higher spatial continuity when compared to $\mathrm{FCO}_{2}$. For sugarcane areas, the Ts spatial patterns maps presented spatial continuity for all the studied days, with patterns of higher homogeneity as compared to the $\mathrm{FCO}_{2}$ and $\mathrm{sH}$ maps.

The results indicate that the $\mathrm{FCO} 2$ spatial patterns could not be described by Ts and Ms spatial patterns for each studied day. It was not observed significant correlation indexes between the $\mathrm{FCO}_{2}$ and the Ts or Ms for the different days except for days 323 and 327, which had negative and significant linear correlation indexes $(p<0.05)$ between $\mathrm{FCO}_{2}$ and $\mathrm{Ms}$ of -0.20 and -0.39 , respectively. In the soil of French Guiana forest, were observed negative and significant correlation coefficients between the soil respiration and $\mathrm{Ms}$ and $\mathrm{pH}$ variables, and positive with Ts and soil carbon (Epron et al., 2006). This positive relation between $\mathrm{FCO}_{2}$ and $T s$ is, probably, due to the activity increase of the presence of microorganisms in the soil with the temperature increase (Lloyd \& Taylor, 1994; Epron et al., 1999; Burton \& Pregitzer, 2003; Epron et al., 2006; Ryu et al., 2009). In Jaboticabal region, SP (Brazil), in sugarcane area, $\mathrm{FCO}_{2}$ presented significant correlation with Ts (0.59) and Ms (-0.53) in the burned sugarcane system, already under mechanized harvesting area, were not observed significant correlations between these attributes and $\mathrm{FCO}_{2}$ (Panosso et al., 2008).

\section{CONCLUSION}

It was not observed correlations between $\mathrm{CO}_{2}$ emissions and the temperature, or the soil moisture in the studied cultures. The spatial variability structure of the soil $\mathrm{CO}_{2}$ emission ranged from studied days for the two agricultural areas, such variation may be related to rain occurrence during the study period. For soybean data, the ranges of spatial dependency and the models adjusted to the $\mathrm{FCO}_{2}$ variograms present large variations during the evaluation days when compared to sugarcane area. Spherical, exponential and Gaussian models were adjusted to the experimental variograms in soybean area, while the exponential model was adjusted to most of evaluation days in sugarcane experiment. The ranges values of spatial dependence of the soil $\mathrm{CO}_{2}$ emission were similar in both cultures; however, the sugarcane area presented smaller variations 
of the ranges values when compared to soybean area.

\section{ACKNOWLEDGEMENTS}

We would like to thanks to CNPq, FAPESP, and UNESP for granting the scientific initiation scholarships and financial support to the developed research.

\section{REFERENCES}

Ball, B. C.; Scott, A.; Parker, J. P. 1999. Field $\mathrm{N} 2 \mathrm{O}, \mathrm{CO} 2$ and $\mathrm{CH} 4$ fluxes in relation to tillage, compaction and soil quality in Scotland. Soil \& Tillage Research, v. 53, n. 1, p. 29-39.

Bicalho, E. S.; Panosso, A. R.; Teixeira, D. D. B.; Miranda, J. G. V.; Pereira, G. T.; LA Scala, N. 2014. Spatial variability structure of soil $\mathrm{CO} 2$ emission and soil attributes in a sugarcane area. Agriculture Ecosystems \& Environment, v. 189 , p. $206-215$.

Brito, L. F.; Marques JR., J.; Pereira, G. T.; La Scala JR, N. 2010. Spatial variability of soil CO2 emission in different topographic positions. Bragantia, v. 69, Suplemento, p. 19-27.

Buczko, U.; Bachmann, S.; Gropp, M.; Jurasinski, G.; Glatzel, S. 2015. Spatial variability at different scales and sampling requirements for in situ soil $\mathrm{CO} 2$ efflux measurements on an arable soil. Catena, v. 131, p. 46-55.

Burton, A. J.; Pregitzer, K. S. 2013. Field measurements of root respiration indicate little to no seasonal temperature acclimation for sugar maple and red pine. Tree Physiology, v. 23, n. 4, p. 273-280.

Cambardella, C. A.; Moorman, T. B.; Novak, J. M.; Parkin, T. B.; Karlen, D. L.; Turco, R. F.;
Konopka, A. E. 1994. Field-scale variability of soil properties in central lowa soils. Soil Science Society of America Journal, v. 58, n. 5, p. 1501-1511.

Cardellini, C.; Chiodini, G.; Frondini, F. 2003. Application of stochastic simulation to $\mathrm{CO} 2$ flux from soil: Mapping and quantification of gas release. Journal of Geophysical ResearchSolid Earth, v. 108, n. B9, p.

Cerri, C. E. P.; Sparovek, G.; Bernoux, M.; Easterling, W. E.; Melillo, J. M.; Cerri, C. C. 2007. Tropical agriculture and global warming: Impacts and mitigation options. Scientia Agricola, v. 64, n. 1, p. 83-99.

CONAB. 2015a. Companhia Nacional de Abastecimento - companhamento da safra brasileira - Quarto levantamento da safra de cana-deaçúcar. v. 2013/2014, p. 30, 2015a.

CONAB. 2015b. Companhia Nacional de Abastecimento - companhamento da safra brasileira - Sétimo levantamento da safra de Grãos. v. 2014/2015, p. 30, 2015b.

Dasselaar, A.; Corre, W. J.; Prieme, A.; Klemedtsson, A. K.; Weslien, P.; Stein, A.; Klemedtsson, L.; Oenema, O. 1998. Spatial variability of methane, nitrous oxide, and carbon dioxide emissions from drained grasslands. Soil Science Society of America Journal, v. 62, n. 3, p. 810-817.

Dominy, C. S.; Haynes, R. J.; Van Antwerpen, R. 2002. Loss of soil organic matter and related soil properties under long-term sugarcane production on two contrasting soils. Biology and Fertility of Soils, v. 36, n. 5, p. 350-356.

EMBRAPA. Sistema brasileiro de classificação de solos. Brasília, 2013. 412 p.

Epron, D.; Bosc, A.; Bonal, D.; Freycon, V. 2006. Spatial variation of soil respiration across a topographic gradient in a tropical rain forest in French Guiana. Journal of Tropical Ecology, v. 22, p. 565-574. 
Epron, D.; Farque, L.; Lucot, E.; Badot, P. M. 1999. Soil CO2 efflux in a beech forest: dependence on soil temperature and soil water content. Annals of Forest Science, v. 56, n. 3, p. 221-226.

Gamma Design Software. GS+: geostatistics for the environmental sciences. Version 3.07. Michigan, Gamma Design Software, 1998.

Gonçalves, A. C. A.; Folegatti, M. V.; Mata, J. D. V. 2001. Análises exploratória e geoestatística da variabilidade de propriedades físicas de um Argissolo Vermelho. Acta Scientiarum, v. 23, n. 5, p. 1149-1157.

Herbst, M.; Prolingheuer, N.; Graf, A.; Huisman, J. A.; Weihermuller, L.; Vanderborght, J.; Vereecken, H. 2010. Multivariate conditional stochastic simulation of soil heterotrophic respiration at plot scale. Geoderma, v. 160, n. 1, p. 74-82.

lamaguti, J. L.; Moitinho, M. R.; Teixeira, D. B.; Bicalho, E. S.; Panosso, A. R.; La Scala JR, N. 2015. Preparo do solo e emissão de CO2, temperatura e Soil Humidityem área canavieira. Revista Brasileira De Engenharia Agricola E Ambiental, v. 19, n. 5, p. 497-504.

IPCC. 2014. Climate Change 2014: impacts, adaptation, and vulnerability. In Contribution of Working Group I to the Fifth Assessment Report of the Intergovernmental Panel on Climate Change, Stocker TF, Qin D, Plattner GK et al. (eds). Cambridge University Press: Cambridge, United Kingdom and New York, NY, USA, 1535 pp, 2014.

Isaaks, E. H.; Srivastava, R. M. 1989. Applied geostatistics. Nova York: Oxford University Press, 1989. 561

Ishizuka, S.; Iswandi, A.; Nakajima, Y.; Yonemura, L.; Sudo, S.; sTuruta, H.; Muriyarso, D. 2005. Spatial patterns of greenhouse gas emission in a tropical rainforest in Indonesia. Nutrient Cycling in Agroecosystems, v. 71, n. 1, p. 55-62.

Kemmitt, S. J.; Lanyon, C. V.; Waite, I. S.; Wen, Q.; Addiscott, T. M.; Bird, N. R. A.; O'donnell, A. G.; Brookes, P. C. 2008. Mineralization of native soil organic matter is not regulated by the size, activity or composition of the soil microbial biomass - a new perspective. Soil Biology \& Biochemistry, v. 40, p. 61-73.

Konda, R.; Ohta, S.; Ishizuka, S.; Arai, S.; Ansori, S.; Tanaka, N.; Hardjono, A. 2008. Spatial structures of $\mathrm{N} 2 \mathrm{O}, \mathrm{CO} 2$, and $\mathrm{CH} 4$ fluxes from Acacia mangium plantation soils during a relatively dry season in Indonesia. Soil Biology \& Biochemistry, v. 40, n. 12, p. 3021-3030.

Kosugi, Y.; Mitani, T.; Ltoh, M.; Noguchi, S.; Tani, M.; Matsuo, N.; Takanashi, S.; Ohkubo, S.; Nik, A. R. 2007. Spatial and temporal variation in soil respiration in a Southeast Asian tropical rainforest. Agricultural and Forest Meteorology, v. 147, p. 35-47.

La Scala JR, N.; Panosso, A. R.; Pereira, G. T. 2003. Variabilidade espacial e temporal da emissão de $\mathrm{CO} 2$ num latossolo desprovido de vegetação. Engenharia Agricola, v. 23, n. 1, p. 88-95.

La Scala, N.; Marques, J.; Pereira, G. T.; Cora, J. E. 2000a. Carbon dioxide emission related to chemical properties of a tropical bare soil. Soil Biology \& Biochemistry, v. 32, n. 10, p. 1469-1473.

La Scala, N.; Marques, J.; Pereira, G. T.; Cora, J. E. 2000b. Short-term temporal changes in the spatial variability model of $\mathrm{CO} 2$ emissions from a Brazilian bare soil. Soil Biology \& Biochemistry, v. 32, n. 10, p. 1459-1462.

Lal, R. 2009. Challenges and opportunities in soil organic matter research. European Journal of Soil Science, v. 60, n. 2, p. 158-169.

Lewicki, J. L.; Bergfeld, D.; Cardellini, C.; Chiodini, G.; Granieri, D.; Varley, N.; Werner, 
C. 2005. Comparative soil CO2 flux measurements and geostatistical estimation methods on Masaya volcano, Nicaragua. Bulletin of Volcanology, v. 68, n. 1, p. 76-90.

Lloyd, J.; Taylor, J. A. 1994. ON THE TEMPERATURE-DEPENDENCE OF SOIL RESPIRATION. Functional Ecology, v. 8, n. 3, p. 315-323.

MAPA. Soybean. 2016. Disponível em: <http://www.agricultura.gov.br/vegetal/cultu ras/soybean>. Acesso em: 20 maio 2016.

Moitinho, M. R.; Pandovan, M. P.; Panosso, A. R.; Teixeira, D. B.; Ferraudo, A. S.; La Scala JR, N. 2015. On the spatial and temporal dependence of $\mathrm{CO} 2$ emission on soil properties in sugarcane (Saccharum spp.) production. Soil \& Tillage Research, v. 148, p. 127-132.

Ohashi, M.; Gyokusen, K. 2007. Temporal change in spatial variability of soil respiration on a slope of Japanese cedar (Cryptomeria japonica D. Don) forest. Soil Biology \& Biochemistry, v. 39, n. 5, p. 1130-1138.

Panosso, A. R.; Marques, J.; Pereira, G. T.; La Scala, N. 2009a. Spatial and temporal variability of soil $\mathrm{CO} 2$ emission in a sugarcane area under green and slash-and-burn managements. Soil \& Tillage Research, v. 105, n. 2, p. 275-282.

Panosso, A. R.; Pereira, G. T.; Marques, J.; La Scala, N. 2008. Spatial Variability of $\mathrm{CO} 2$ emission on oxisol soils cultivated with sugarcane under different management practices. Engenharia Agricola, v. 28, n. 2, p. 227-236.

Panosso, A. R.; Perillo, L. I.; Ferraudo, A. S.; Pereira, G. T.; Miranda, J. G. V.; La Scala JR, N. 2012. Fractal dimension and anisotropy of soil CO2 emission in a mechanically harvested sugarcane production area. Soil \& Tillage Research, v. 124, p. 8-16.
Panosso, A. R.; Ribeiro, C. E. R.; Zanini, J. R.; Pavani, L. C.; Pereira, G. T.; La Scala, N. 2009b. Spatial variability of $\mathrm{CO} 2$ emission, temperature and moisture of a bare oxisol submitted to different wetting levels. SeminaCiencias Agrarias, v. 30, n., p. 1017-1033.

Piotrowska, A.; Dlugosz, J. 2012. Spatiotemporal variability of microbial biomass content and activities related to some physicochemical properties of Luvisols. Geoderma, v. 173, p. 199-208.

Pringle, M. J.; Lark, R. M. 2006. Spatial analysis of model error, illustrated by soil carbon dioxide emissions. Vadose Zone Journal, v. 5, n. 1, p. 168-183.

Rayment, M. B.; Jarvis, P. G. 2000. Temporal and spatial variation of soil $\mathrm{CO} 2$ efflux in a CanaDayn boreal forest. Soil Biology \& Biochemistry, v. 32, n. 1, p. 35-45.

Rochette, P.; Desjardins, R. L.; Pattey, E. 1991. Spatial and temporal variability of soil respiration in agricultural fields. CanaDayn Journal of Soil Science, v. 71, n. 2, p. 189-196.

Ryu, S. R.; Concilio, A.; Chen, J. Q.; North, M.; MA, S. Y. 2009. Prescribed burning and mechanical thinning effects on belowground conditions and soil respiration in a mixedconifer forest, California. Forest Ecology and Management, v. 257, n. 4, p. 1324-1332.

Schwendenmann, L.; Veldkamp, E.; Brenes, T.; O'brien, J. J.; Mackensen, J. 2003. Spatial, and temporal variation in soil $\mathrm{CO} 2$ efflux in an oldgrowth neotropical rain forest, La Selva, Costa Rica. Biogeochemistry, v. 64, n. 1, p. 111-128.

Silva-Olaya, A. M.; Cerri, C. E. P.; La Scala, N., JR.; Days, C. T. S.; Cerri, C. C. 2013. Carbon dioxide emissions under different soil tillage systems in mechanically harvested sugarcane. Environmental Research Letters, v. 8, n. 1, p.

Stoyan, H.; De-Polli, H.; Bohm, S.; Robertson, G. P.; Paul, E. A. 2000. Spatial heterogeneity of soil respiration and related properties at 
the plant scale. Plant and Soil, v. 222, n. 1-2, p. 203-214.

Teixeira, D. B.; Bicalho, E. S.; Panosso, A. R.; Perillo, L. I.; Iamaguti, J. L.; Pereira, G. T.; La Scala JR, N. 2012. Uncertainties in the prediction of spatial variability of soil $\mathrm{CO} 2$ emissions and related properties. Revista Brasileira de Ciência do Solo, v. 36, n. 5, p. 1466-1475.

Teixeira, D. B.; Panosso, A. R.; Cerri, C. E. P.; Pereira, G. T.; La Scala, N. 2011. Soil CO(2) emission estimated by different interpolation techniques. Plant and Soil, v. 345, n. 1-2, p. 187-194.

Trangmar, B. B.; Yost, R. S.; Uehara, G. 1985. Application of geostatistics to spatial studies of soil properties. Advances in Agronomy, v. 38, p. 45-94.

Warrick, A. W.; Nielsen, D. R. 1980. Spatial variability of soil physical properties in the field, In: Hillel, D. (Ed.), Applications of soil physics. New York: Academic Press, 1980. p. 319-344.

Webster, R.; Oliver, M. A. 1990. Statistical methods in soil and land resource survey. New York: Oxford University Press, 1990. 328 p.

Webster, R.; Oliver, M. A. 2009.Geostatistics for Environmental Scientists. Oxford: Oxford University Press, 2009. 315 p. 